\title{
Ionic Mechanism of Ouabain-Induced Concurrent Apoptosis and Necrosis in Individual Cultured Cortical Neurons
}

\author{
Ai Ying Xiao, Ling Wei, Shuli Xia, Steven Rothman, and Shan Ping Yu \\ Department of Neurology and Center for the Study of Nervous System Injury, Washington University School of Medicine, \\ St. Louis, Missouri 63110
}

Energy deficiency and dysfunction of the $\mathrm{Na}^{+}, \mathrm{K}^{+}$-ATPase are common consequences of many pathological insults. The nature and mechanism of cell injury induced by impaired $\mathrm{Na}^{+}$, $\mathrm{K}^{+}$-ATPase, however, are not well defined. We used cultured cortical neurons to examine the hypothesis that blocking the $\mathrm{Na}^{+}, \mathrm{K}^{+}$-ATPase induces apoptosis by depleting cellular $\mathrm{K}^{+}$ and, concurrently, induces necrotic injury in the same cells by increasing intracellular $\mathrm{Ca}^{2+}$ and $\mathrm{Na}^{+}$.

The $\mathrm{Na}^{+}, \mathrm{K}^{+}$-ATPase inhibitor ouabain induced concentrationdependent neuronal death. Ouabain triggered transient neuronal cell swelling followed by cell shrinkage, accompanied by intracellular $\mathrm{Ca}^{2+}$ and $\mathrm{Na}^{+}$increase, $\mathrm{K}^{+}$decrease, cytochrome $c$ release, caspase- 3 activation, and DNA laddering. Electron microscopy revealed the coexistence of ultrastructural features of both apoptosis and necrosis in individual cells. The caspase inhibitor Z-Val-Ala-Asp(OMe)-fluoromethyl ketone (Z-VADFMK) blocked $>50 \%$ of ouabain-induced neuronal death. Potassium channel blockers or high $\mathrm{K}^{+}$medium, but not $\mathrm{Ca}^{2+}$ channel blockade, prevented cytochrome $c$ release, caspase activation, and DNA damage. Blocking of $\mathrm{K}^{+}, \mathrm{Ca}^{2+}$, or $\mathrm{Na}^{+}$ channels or high $\mathrm{K}^{+}$medium each attenuated the ouabaininduced cell death; combined inhibition of $\mathrm{K}^{+}$channels and $\mathrm{Ca}^{2+}$ or $\mathrm{Na}^{+}$channels resulted in additional protection. Moreover, coapplication of Z-VAD-FMK and nifedipine produced virtually complete neuroprotection.

These results suggest that the neuronal death associated with $\mathrm{Na}^{+}, \mathrm{K}^{+}$-pump failure consists of concurrent apoptotic and necrotic components, mediated by intracellular depletion of $\mathrm{K}^{+}$and accumulation of $\mathrm{Ca}^{2+}$ and $\mathrm{Na}^{+}$, respectively. The ouabain-induced hybrid death may represent a distinct form of cell death related to the brain injury of inadequate energy supply and disrupted ion homeostasis.

Key words: $\mathrm{Na}^{+}, \mathrm{K}^{+}$-ATPase; apoptosis; necrosis; hybrid death; potassium channel; calcium; caspase; cytochrome c; DNA fragmentation; ouabain; strophanthidin
Apoptosis may play important roles in various disease states (Raff et al., 1993; Ameisen, 1994; Thompson, 1995; Reed, 1999). Neuronal apoptosis occurs after an ischemic insult in the brain (Schumer et al., 1992; Chopp and Li, 1996; Du et al., 1996) and after spinal cord injury (Liu et al., 1997). Apoptosis is controlled by an internally encoded suicide program executed by activation of endogenous proteases (caspases) and endonucleases (Vaux et al., 1994; Kroemer et al., 1995; Miura and Yuan, 1996). Although multiple stimuli and signal pathways may contribute to apoptosis in a wide range of cell types, apoptotic cells share similar characteristic morphologies such as cell shrinkage, nuclear/chromatin condensation, internucleosomal cleavage of DNA, membrane blebbing, and formation of apoptotic bodies (Kerr et al., 1972; Wyllie et al., 1980; Mills et al., 1999). In contrast, necrosis is distinct from apoptosis in both morphological and biochemical characteristics; it begins with the swelling of cell body and mitochondrial contents, followed by vacuolization of cytoplasm, irregular breakdown of nuclear DNA, rupture of the cell membrane, and cell lysis (Majno and Joris, 1995).

The striking differences in cell volume changes imply that

\footnotetext{
Received April 6, 2001; revised Nov. 13, 2001; accepted Nov. 27, 2001.

This work was supported by grants from the National Science Foundation (9950207N to S.P.Y.), the American Heart Association (IBN-9817151 and 0170064N to S.P.Y.), and National Institutes of Health (NS37337 to L.W. and NS37773 to S.R.).

Correspondence should be addressed to Shan Ping Yu, Department of Neurology, Box 8111, 660 South Euclid Avenue, Washington University School of Medicine, St. Louis, MO 63110. E-mail: yus@neuro.wustl.edu.

Copyright (C) 2002 Society for Neuroscience $0270-6474 / 02 / 221350-13 \$ 15.00 / 0$
}

necrosis and apoptosis possess distinguishable ionic mechanisms. Excessive $\mathrm{Ca}^{2+}$ and $\mathrm{Na}^{+}$influx and their accumulation in the intracellular space are most likely responsible for cell swelling and necrotic death (Choi, 1988). On the other hand, excessive $\mathrm{K}^{+}$ efflux and intracellular $\mathrm{K}^{+}$depletion may play key roles in cell shrinkage, caspase/endonuclease activation, and apoptotic death (Beauvais et al., 1995; Bortner et al., 1997; Yu et al., 1997, 1998; Dallaporta et al., 1998).

Under the "apoptosis versus necrosis" classification, cell death is generally divided into these two categories; however, it is sometimes difficult to exclusively place a cell injury into either group. For example, the exact type of cell death after brain ischemia has been under debate (Deshpande et al., 1992; van Lookeren Campagne and Gill, 1996; Colbourne et al., 1999; Nicotera and Lipton, 1999). Alternatively, it was suggested that these two processes can occur simultaneously in tissues or cell cultures that have been exposed to a toxic stimulus (Ankarcrona et al., 1995; Leist et al., 1996; Shimizu et al., 1996). These discussions dictate reassessment of "mixed cell death" as a heterogeneous entity combining both active and passive cell death (Hirsch et al., 1997; Kim et al., 1999; Yu et al., 1999a). Consistently, recent evidence showed an in vivo "apoptosis-necrosis continuum" in excitotoxically lesioned rat brain (Portera-Cailliau et al., 1997).

The present study extends this concept even further, showing, for the first time, the simultaneous appearance of apoptotic and necrotic features in individual cells destined to die after exposure to a $\mathrm{Na}^{+}, \mathrm{K}^{+}$-ATPase inhibitor. The $\mathrm{Na}^{+}, \mathrm{K}^{+}$-ATPase, or $\mathrm{Na}^{+}$, 
$\mathrm{K}^{+}$-pump, is a critical player in maintaining ionic homeostasis; blocking the $\mathrm{Na}^{+}, \mathrm{K}^{+}$-pump concomitantly reduces intracellular $\mathrm{K}^{+}$and increases $\mathrm{Ca}^{2+}$ and $\mathrm{Na}^{+}$(Budzikowski et al., 1998; Balzan et al. 2000; Ferrandi and Manunta, 2000). We demonstrate that loss of intracellular $\mathrm{K}^{+}$and gain of $\mathrm{Ca}^{2+}$ and $\mathrm{Na}^{+}$are responsible for apoptotic and necrotic injuries in the same cells, respectively. The study of the ionic mechanisms of hybrid cell death further verified a key role for $\mathrm{K}^{+}$in cytochrome $c$ release, caspase activation, and DNA damage.

This work has been published previously in abstract form (Xiao and Yu, 2000).

\section{MATERIALS AND METHODS}

Neocortical cultures. Near pure-neuronal cultures and mixed cortical cultures (containing neurons and a confluent glia bed) were prepared as described previously (Rose et al., 1993). Briefly, neocortices were obtained at 15-17 d gestation from fetal mice. They were dissociated and plated onto a poly-D-lysine- and laminin-coated base (near-pure neuronal culture) or a previously established glial monolayer (mixed culture), at a density of $0.35-0.40$ hemispheres $/ \mathrm{ml}$ in 24- or 96-well plates or $35 \mathrm{~mm}$ dishes (Falcon, Primaria) depending on experimental requests. Cultures were maintained in Eagle's minimal essential medium (MEM; Earle's salts) supplemented with $20 \mathrm{~mm}$ glucose, $5 \%$ fetal bovine serum (FBS), and $5 \%$ horse serum (HS). For the pure neuron cultures, cytosine arabinoside (final concentration, $10 \mu \mathrm{M}$ ) was added $3 \mathrm{~d}$ later to inhibit glial cell growth and cell division, and no medium change was performed until experiments on 11-12 d in vitro (DIV) or at a specified DIV. For the mixed cultures, medium was changed after 1 week to MEM containing 20 $\mathrm{mm}$ glucose and $10 \% \mathrm{HS}$, as well as cytosine arabinoside $(10 \mu \mathrm{M})$ to inhibit cell division. Glial cultures used for glia toxicity and for mixed cultures were prepared from dissociated neocortices of postnatal day 1-3 mice. Cells were plated at a density of 0.06 hemispheres $/ \mathrm{ml}$ in Eagle's MEM containing $20 \mathrm{~mm}$ glucose, $10 \% \mathrm{FBS}, 10 \% \mathrm{HS}$, and $10 \mathrm{ng} / \mathrm{ml}$ epidermal growth factor (EGF); a confluent glial bed was formed in 1-2 weeks. Neuronal identity was confirmed previously by Nissl staining and electrophysiological characteristics; the glial bed was identified by immunoreactivity for glial fibrillary acidic protein (Rose et al., 1993).

Assessment of cell death. Neuronal cell death was assessed in 24-well plates by measuring lactate dehydrogenase (LDH) released into the bathing medium (MEM $+20 \mathrm{~mm}$ glucose and $30 \mathrm{~mm} \mathrm{NaHCO}_{3}$ ), using a multiple plate reader (Molecular Devices, Sunnyvale, CA), and confirmed by staining DNA with propidium iodide (PI) followed by quantification using a fluorometric plate reader (PerSeptive Biosystems, Framingham, MA). Validation of apoptotic or necrotic neuronal death using LDH release and PI staining has been performed previously (Gottron et al., 1997). Neuronal loss is expressed as either a percentage of LDH released or fluorescence measured in each experimental condition normalized to the negative (sham wash) and positive controls (complete neuronal death induced by $24 \mathrm{hr}$ exposure to $300 \mu \mathrm{M}$ NMDA or cell death induced by ouabain alone). There was no significant glial death detected by trypan blue exclusion in injury paradigms except with high concentrations of ouabain (see Fig. 1C).

Cell volume assay. Cell volume was determined from the maximum cross-sectional area of a cell, assuming that the cell soma swells and shrinks in a spherical manner. This assumption has been validated in neocortical cultures, where cell volume changes measured directly, using optical sectioning techniques, were no difference from those calculated from the cross-sectional area (Churchwell et al., 1996). Measurement of cross-sectional areas was performed using the MetaMorph Imaging System (Universal Imaging Corporation, West Chester, PA). Area values were normalized to sham controls, expressed as relative cell volume changes.

Caspase activity assay. Caspase activity was measured as described previously by Armstrong et al. (1997). Briefly, cultures were washed three times with PBS and lysed in $80 \mu \mathrm{l}$ of buffer A (10 mM HEPES, $42 \mathrm{~mm}$ $\mathrm{KCl}, 5 \mathrm{~mm} \mathrm{MgCl}_{2}, 1 \mathrm{~mm}$ DTT, $1 \%$ Triton X-100, $1 \mathrm{~mm}$ PMSF, $1 \mu \mathrm{g} / \mathrm{ml}$ leupeptin, $\mathrm{pH} 7.4)$. Lysate $(10 \mu \mathrm{l})$ was combined in a 96-well plate with $90 \mu \mathrm{l}$ of buffer B (10 mM HEPES, $42 \mathrm{~mm} \mathrm{KCl,} 5 \mathrm{~mm} \mathrm{MgCl}_{2}, 1 \mathrm{~mm}$ DTT, $1 \%$ Triton $\mathrm{X}-100,10 \%$ sucrose, $\mathrm{pH}$ 7.4) containing fluorometric substrate $(30 \mu \mathrm{M})$ and incubated for $45 \mathrm{~min}$ at room temperature in the dark. Formation of fluorogenic product was determined in a cytofluor fluorometric plate reader by measuring emission at $460 \mathrm{~nm}$ with $360 \mathrm{~nm}$ excitation. Caspase-3-like activity was correlated with cleavage of
$N$-acetyl-Asp-Glu-Val-Asp-7-amino-4-methylcoumarin (DEVD-AMC) (Thornberry et al., 1997).

Cytochrome c release. Cytochrome $c$ release from mitochondria was determined by Western blot. Cells were harvested by centrifugation at $200 \times g$ for $10 \mathrm{~min}$ at $4^{\circ} \mathrm{C}$. The cell pellets were then resuspended in 50 $\mu l$ of extraction buffer (220 mm mannitol, $68 \mathrm{~mm}$ sucrose, $50 \mathrm{~mm}$ PIPES$\mathrm{KOH}, 50 \mathrm{~mm} \mathrm{KCl,} 5 \mathrm{~mm}$ EGTA, $2 \mathrm{~mm} \mathrm{MgCl}$, $1 \mathrm{~mm}$ EDTA, 1 mm DTT, $10 \mu \mathrm{g} / \mathrm{ml}$ leupeptin, $10 \mu \mathrm{g} / \mathrm{ml}$ aprotinin, $\mathrm{pH}$ 7.4). After chilling on ice for $30 \mathrm{~min}$, cells were homogenized by the Bio-Vortexer Mixer (No. 1083MC, Research Products International, Mt. Prospect, IL). The homogenate was centrifuged at $750 \times g$ at $4^{\circ} \mathrm{C}$ and then at $8000 \times g$ for $20 \mathrm{~min}$ at $4^{\circ} \mathrm{C}$. The $8000 \times g$ pellets were used to obtain the mitochondrial fraction. The supernatant was further centrifuged at $13,000 \times g$ for 60 min at $4^{\circ} \mathrm{C}$. Protein concentrations were determined by the BCA protein assay kit (Pierce Inc., Rockford, IL). Approximately 15-35 $\mu \mathrm{g}$ of protein extracts from cytosol or mitochondria were boiled for $5 \mathrm{~min}$ and analyzed on a $14 \%$ SDS-polyacrylamide electrophoresis gel and resolved under reducing condition for $90 \mathrm{~min}$ at $120 \mathrm{~V}$. Separated proteins were then electroblotted onto polyvinylidene difluoride membranes at $130 \mathrm{~mA}$ for $60 \mathrm{~min}$. Cytochrome $c$ was detected using a monoclonal antibody to cytochrome $c$ (PharMingen, San Diego, CA) at a dilution of 1:500. Cytochrome oxidase (COX) was detected using $1 \mu \mathrm{g} / \mathrm{ml}$ 20E8C12 COX subunit IV monoclonal (Molecular Probes, Eugene, OR). Blots were developed using an alkaline phosphatase-conjugated secondary antibody (1:1000) and visualized using chromogenic substrates (ProtoBlot Western Blot AP System Kit, Promega, Madison, WI). Western blot analysis of $\beta$-actin was performed with horseradish peroxidase-conjugated antimouse IgG reagents (Sigma Aldrich, St. Louis, MO).

Determination of DNA fragmentation. Cells were washed in PBS, resuspended in lysis buffer $(10 \mathrm{~mm}$ Tris- $\mathrm{HCl}, 100 \mathrm{~mm}$ EDTA, $0.5 \%$ SDS, $\mathrm{pH}$ 8.0) for $5 \mathrm{~min}$ at room temperature, and then treated with Proteinase $\mathrm{K}(300 \mu \mathrm{g} / \mathrm{ml})$ for $2 \mathrm{hr}$ at $50^{\circ} \mathrm{C}$. DNA was precipitated overnight at $4^{\circ} \mathrm{C}$ by adding $\mathrm{NaCl}$ to a final concentration of $1 \mathrm{M}$. The lysate was centrifuged at $13,000 \mathrm{rpm}$ for $1 \mathrm{hr}$ at $4^{\circ} \mathrm{C}$ followed by extraction of DNA with phenol/chloroform/isoamyl alcohol (25:24:1). The total DNA contained in the aqueous phase was precipitated with isopropanol. The DNA pellet was washed twice with $70 \%$ ethanol and resuspended in TE buffer $(10$ $\mathrm{mm}$ Tris-Cl, $1 \mathrm{~mm}$ EDTA, $\mathrm{pH}$ 7.4) containing RNase at $0.3 \mathrm{mg} / \mathrm{ml}$. Aliquots (10-15 $\mu \mathrm{g}$ of DNA) were analyzed on a $1.5 \%$ Agarose gel that was run at $75 \mathrm{~V}$ for $3 \mathrm{hr}$. After electrophoresis and staining with ethidium bromide, the gel was visualized under ultraviolet light and photographed.

Cellular ion measurements. Intracellular $\mathrm{K}^{+}$content was measured using a $\mathrm{K}^{+}$-sensitive electrode and inductively coupled plasma mass spectrometry (ICP-MS). Intracellular $\mathrm{Ca}^{2+}$ and $\mathrm{Na}^{+}$contents were measured by ICP-MS. The ICP-MS technique has been used for determination of trace elements in various materials, including biological samples (Ejima et al., 1999).

The mixed and pure neuronal cortical cultures were washed three times at the indicated times with a $\mathrm{K}^{+}$-free, $\mathrm{Na}^{+}$-free, or $\mathrm{Ca}^{2+}$-free solution containing $120 \mathrm{~mm} \mathrm{~N}$-methyl-D-glucamine (NMDG), $2 \mathrm{~mm}$ $\mathrm{MgCl}_{2}, 10 \mathrm{~mm}$ glucose, and $10 \mathrm{~mm}$ HEPES, $\mathrm{pH}$ 7.3. Immediately after removal of the wash solution, $0.1 \%$ Triton X-100 (25-50 $\mu \mathrm{l})$ was added to each well, and solutions from four wells were combined for measurement in triplicate. Comparable cell density in wells was confirmed by protein content measured by the BCA protein assay kit (Pierce), and the ion measurements were normalized to the protein content.

For ICP-MS assay, $1 \%$ nitric acid was added to a final volume of $1 \mathrm{ml}$, and the sample was digested with a CEM $950 \mathrm{~W}$ model 2100 Microwave (CEM Corporation, Matthews, NC). The analyses were performed with a Finnigan Element HR-ICP-Mass spectrometer (Bremen, Germany). Indium was used as an internal standard to compensate for changes in analytical signals during the operation. Analytical conditions and performance of the instrument specific to $\mathrm{Na}^{+}, \mathrm{Ca}^{2+}$, and $\mathrm{K}^{+}$are summarized in Table 1. Standards of different concentrations were used for construction of the calibration curves for $\mathrm{Na}^{+}, \mathrm{Ca}^{2+}$, and $\mathrm{K}^{+}$assays. Data were corrected for the microwave blank, dilution, and volume of original sample.

Calcium imaging. Intracellular free $\mathrm{Ca}^{2+}\left(\left[\mathrm{Ca}^{2+}\right]_{\mathrm{i}}\right)$ in neuronal cell bodies was measured using ratiometric fluorescence imaging with Fura-2 AM (Teflabs, Houston, TX). Fura-2 AM (5 $\mu \mathrm{M})$ was bath loaded into neurons at $37^{\circ} \mathrm{C}$ for $1 \mathrm{hr}$ followed by another hour of incubation at room temperature. Fluorescent cells were imaged on an inverted microscope (Nikon Diaphot, Nikon, Melville, NY) using a 40×, 1.3 numerical aperture (NA) fluorite oil immersion objective (Nikon) and a cooled charge-coupled device camera (Sensys, Photometrics, Tucson, AZ). A 75 


\begin{tabular}{llll}
\hline \multicolumn{2}{l}{ Table 1. Experimental conditions of ICP-MS analysis for sodium, calcium, and potassium } & & \\
Item & Sodium & Calcium & \multicolumn{1}{c}{ Potassium } \\
\hline Selected isotope & ${ }^{23} \mathrm{Na}$ & ${ }^{44} \mathrm{Ca}$ & ${ }^{39} \mathrm{~K}$ \\
Chamber gas (sample gas; $1 / \mathrm{min})$ & $0.98-1.00$ & $0.98-1.00$ & $1.01-1.05$ \\
Internal standard (Indium; $\mu \mathrm{g} / \mathrm{l})$ & 10 & 10 & 10 \\
Calibration linear fit & $R=0.99991-0.99999$ & $R=0.99996-1.0000$ & $R=0.99995-1.0000$ \\
Lower and upper limits of calibration $(\mu \mathrm{g} / \mathrm{l})$ & $22.07,2207$ & $31.04,3104$ & $2.356,984.06$ \\
Accuracy (SRM 1643d) & & $31.0 \pm 0.5$ & $2.356 \pm 0.35$ \\
$\quad$ Certified value (mg/l) & $22.07 \pm 0.64$ & $34.0 \pm 1$ & $2.2 \pm 0.1$ or $2.32 \pm 0.3$ \\
$\quad$ Measured value (mg/l) & $24 \pm 1$ &
\end{tabular}

W xenon arc lamp was used to provide fluorescence excitation. Ratio images were obtained by acquiring pairs of images at alternate excitation wavelengths $(340 / 380 \mathrm{~nm})$ and filtering the emission at $510 \mathrm{~nm}$. Image acquisition and processing were controlled by a computer connected to the camera and filter wheel, using the commercial software Metafluor (Universal Imaging Corporation). A background image for each wavelength was acquired from a field lacking fluorescent neurons and subtracted from each pair of fluorescent images. The actual $\mathrm{Ca}^{2+}$ in the region of interest was calculated from the formula: $\left[\mathrm{Ca}^{2+}\right]_{\mathrm{i}}=K_{\mathrm{d}} B(R-$ $\left.R_{\min }\right) /\left(R_{\max }-R\right)$, where $K_{\mathrm{d}}$ is the Fura-2 dissociation constant for $\mathrm{Ca}^{2+}$ $(224 \mathrm{nM}) ; R$ is the average ratio of fluorescence intensity at 340 and 380 $\mathrm{nm}$ wavelength in the region of interest; $R_{\max }$ and $R_{\min }$ are the ratios at saturating $\mathrm{Ca}^{2+}$ and zero $\mathrm{Ca}^{2+}$, respectively; $B$ is the ratio of the fluorescence intensity of the $380 \mathrm{~nm}$ wavelength at zero and saturating $\mathrm{Ca}^{2+}$ (Grynkiewicz et al., 1985). $R_{\min }, R_{\max }$, and $B$ for Fura-2 on our microscope were determined by imaging a droplet $(20 \mu \mathrm{l})$ that evenly filled the microscopic field and contained 0 or $2 \mathrm{mM} \mathrm{Ca}^{2+}, 25 \mu \mathrm{M}$ Fura- $2 / \mathrm{K}^{+}$, and an artificial intracellular solution. The concentration of Fura-2 in the calibration solution was selected to provide fluorescence intensity similar to that of dye-loaded neurons.

Electron microscopy. Cultures in $35 \mathrm{~mm}$ dishes were fixed in glutaraldehyde (1\% glutaraldehyde, $0.1 \mathrm{M}$ sodium cacodylate buffer, $\mathrm{pH}$ 7.4) for $30 \mathrm{~min}$ at $4^{\circ} \mathrm{C}$, washed with $0.1 \mathrm{M}$ sodium cacodylate buffer, and post-fixed in $1.25 \%$ osmium tetroxide for $30 \mathrm{~min}$. Cells were then stained en bloc in $4 \%$ aqueous uranyl acetate for $1 \mathrm{hr}$, dehydrated through a graded ethanol series, embedded in Poly/Bed 812 resin (Polysciences Inc., Warrington, $\mathrm{PA})$, and polymerized in a $60^{\circ} \mathrm{C}$ oven overnight. Thin sections $(62 \mathrm{~nm})$ were cut on a Reichert Ultracut Ultramicrotome (Mager Scientific, Dexter, MI), mounted on 150-mesh copper grids, and post-stained in uranyl acetate and Reynold's lead citrate. Sections were photographed using a transmission electronic microscope (Zeiss 902, LEO Electronic).

Chemicals. The caspase inhibitor Z-VAD-FMK and an inactive analog $\mathrm{N}$-benzyloxycarbonyl Phe-Ala fluoromethylketone (ZFA) were obtained from Enzyme Systems Products (Dublin, CA); the colorimetric substrate Ac-DEVD-AMC and the caspase-1 inhibitor Boc-Asp(OBzl)-CMK were purchased from Calbiochem (San Diego, CA); MK-801 and nifedipine were from RBI (Natick, MA). All other chemicals were purchased from Sigma Aldrich.

Statistics. We used Student's two-tailed $t$ test for comparison of two experimental groups; multiple comparisons were done using one-way ANOVA followed by Dunnett's test for comparison with a single control group, or by the Tukey or Student-Newman-Keuls test for multiple pairwise comparisons. We report mean values \pm SEM; changes were identified as significant if the $p$ value was $<0.05$.

\section{RESULTS}

\section{Effect of ouabain on pure-neuronal and pure-glial cultures}

Ouabain toxicity was first examined in the pure-neuronal cultures. Because ouabain induces membrane depolarization and may indirectly cause excitotoxicity attributable to an enhanced glutamate release, the NMDA receptor antagonist MK-801 $(1 \mu \mathrm{M})$ was coapplied with ouabain. In the presence of MK-801 alone, $\mathrm{LDH}$ release was within the normal range of $\sim 50 \mathrm{U} / \mathrm{ml}(34 \pm 9 \mathrm{U} / \mathrm{ml}$ in sham controls and $61 \pm 7 \mathrm{U} / \mathrm{ml}$ after $24 \mathrm{hr}$ in MK-801; $453 \pm 21$ $\mathrm{U} / \mathrm{ml} \mathrm{LDH}$ was released by the full-kill insult of $300 \mu \mathrm{M}$ NMDA in sister cultures; $n=8$ cultures for each group). After 10-15 hr incubation with ouabain $(80 \mu \mathrm{M})$ and MK-801 $(1 \mu \mathrm{M})$, no cell death was detected. However, there was a decrease in cell volume (the maximum cross-sectional area was decreased by $11 \pm 1 \%$ from $231.5 \pm 4.3$ to $205.6 \pm 5.0 \mu \mathrm{m}^{2} ; n=50$ cells; $\left.p<0.05\right)$ and a marked $\mathrm{K}^{+}$depletion in the cytosolic compartment $(72 \pm 10 \%$ loss; $n=3$ measurements; $p<0.05$ ), which was attenuated by the $\mathrm{K}^{+}$channel blocker tetraethylammonium (TEA) $\left(5 \mathrm{~mm} ; \mathrm{K}^{+}\right.$loss was reduced to $42 \pm 4 \% ; n=3 ; p<0.05)$. By $20 \mathrm{hr}$ with ouabain, neurons shrank by $18 \pm 1 \%$ (the cross-sectional area $=189.8 \pm$ $4.7 \mu \mathrm{m}^{2} ; n=50 ; p<0.05$ ) (Fig. $1 A$ ). A $24 \mathrm{hr}$ exposure to $80 \mu \mathrm{M}$ ouabain and $1 \mu \mathrm{M} \mathrm{MK}-801$ induced $30 \pm 5 \%$ cell death $(n=8$ cultures). Twenty-four hours after the exposure and after three washes, the protein content in culture wells treated with ouabain was similar to sham controls $(1.7 \pm 0.2$ and $1.3 \pm 0.2 \mathrm{mg} / \mathrm{ml}$ for ouabain and control groups; $n=3 ; p>0.05)$, confirming that there was no cell detachment induced by the ouabain treatment as reported in certain epithelial cells (Contreras et al., 1999).

The broad-spectrum caspase inhibitor Z-VAD-FMK (100 $\mu \mathrm{M})$, which completely blocked caspase-3 cleavage (Polverino and Patterson, 1997) (also see Fig. 5), attenuated $62 \pm 7 \%$ of ouabaininduced neuronal death (Fig. $1 B)$. On the contrary, ZFA (100 $\mu \mathrm{M}$ ), an inactive Z-VAD-FMK analog, showed no significant protection against ouabain-induced cell death (data not shown). The large effect of Z-VAD-FMK suggested that there was a significant apoptotic component in ouabain toxicity, but also indicated a component insensitive to caspase blockade. Consistent with a major role of $\mathrm{K}^{+}$loss in ouabain toxicity, TEA ( $\left.5 \mathrm{~mm}\right)$ and elevated extracellular $\mathrm{K}^{+}$concentration (from 5 to $25 \mathrm{~mm}$ ) attenuated the neuronal death (Fig. $1 B$ ). The L-type $\mathrm{Ca}^{2+}$ channel antagonist nifedipine $(1 \mu \mathrm{M})$ also showed marked neuroprotection against ouabain toxicity, suggesting a $\mathrm{Ca}^{2+}$ influxmediated injury component (Fig. $1 B$ ).

In contrast to neurons, glial cells were less sensitive to ouabain. As assessed by LDH release or PI staining, ouabain exposure for $48 \mathrm{hr}$ at concentrations up to $200 \mu \mathrm{M}$ showed no toxic effects on pure glial cultures (Fig. 1C). This observation is consistent with reports that the $\alpha 3$ isoform of $\mathrm{Na}^{+}, \mathrm{K}^{+}$-ATPase, which exhibits high affinity for ouabain, is expressed in neurons but not in glial cells (McGrail et al., 1991; Watts et al., 1991). The selective neuronal injury by ouabain at low concentrations allowed us next to examine ouabain-induced neuronal death in cortical neuronglia cultures, a condition more closely mimicking the in vivo environment.

\section{Ouabain induced cell volume changes and neuronal death in neuron-glia cultures}

Ouabain reduced neuronal viability in cortical neuron-glia cultures in a concentration-dependent manner (Fig. 2A). MK-801 (1 $\mu \mathrm{M})$ was coapplied to prevent glutamate-induced excitotoxicity. 
A

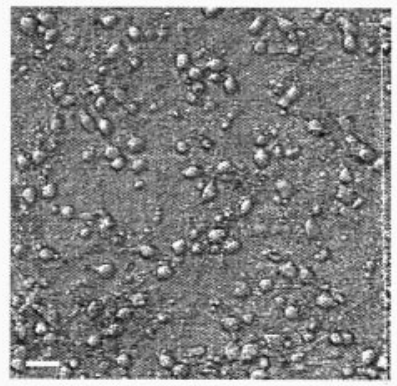

Control

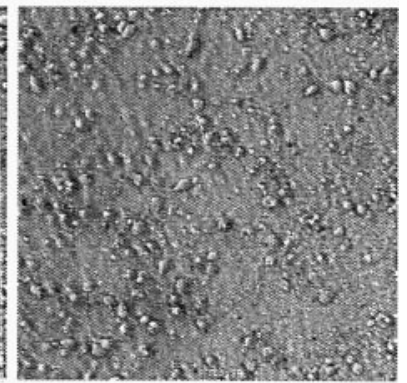

Ouabain
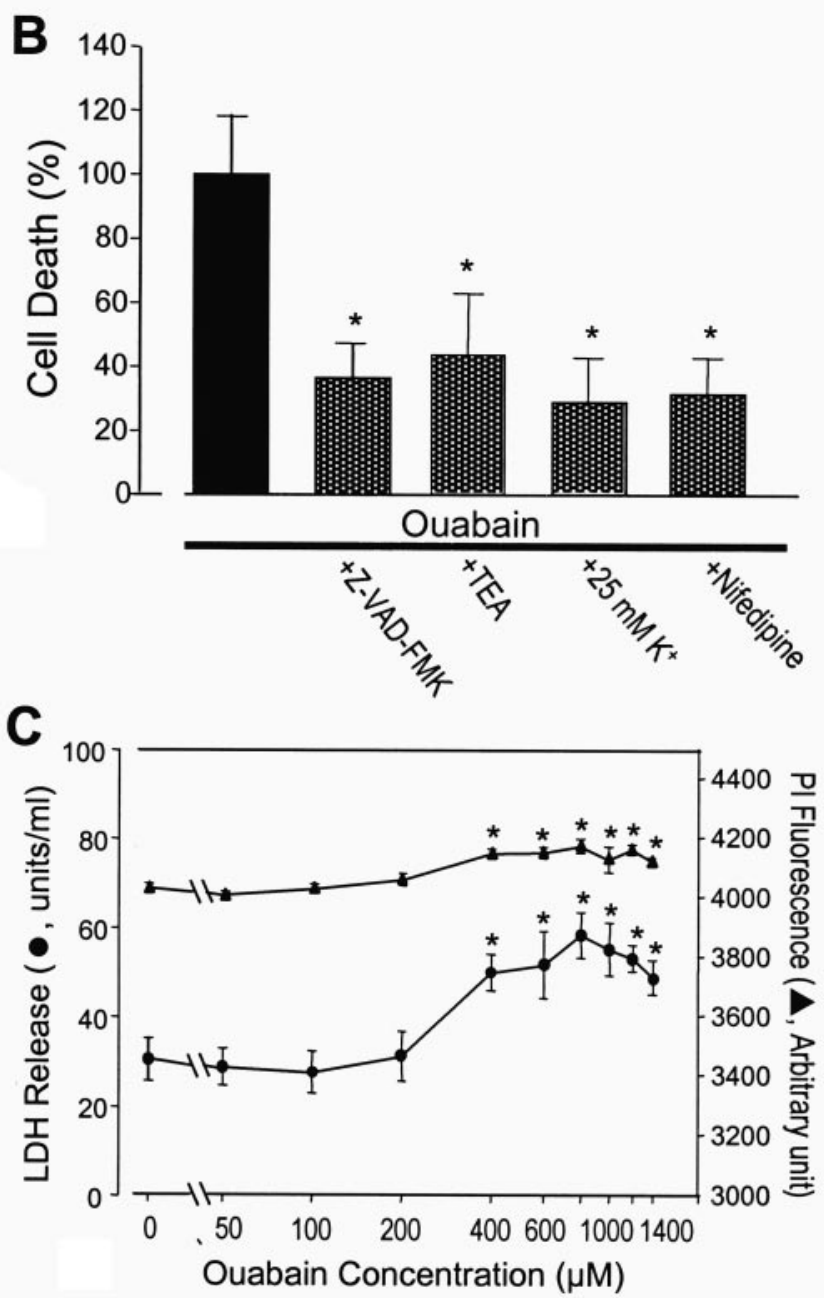

Figure 1. Effects of ouabain on pure-neuronal and pure-glial cultures. $A$, Phase-contrast micrographs of pure-neuronal cultures show control neurons and neurons displaying cell shrinkage and cell degeneration after $20 \mathrm{hr}$ exposure to $80 \mu \mathrm{M}$ ouabain and $1 \mu \mathrm{M} \mathrm{MK}-801$. Scale bar, $50 \mu \mathrm{m}$. $B$, Ouabain $(80 \mu \mathrm{M})$, in the presence of $1 \mu \mathrm{M} \mathrm{MK}-801$, caused significant cell death in pure-neuronal cultures in $24 \mathrm{hr}$. The ouabain-induced neuronal death, normalized as $100 \%$, was drastically reduced by the caspase inhibitor Z-VADFMK $(100 \mu \mathrm{M})$. The $\mathrm{K}^{+}$channel blocker TEA $(5 \mathrm{mM})$ and the $\mathrm{Ca}^{2+}$ channel antagonist nifedipine $(1 \mu \mathrm{M})$ attenuated the ouabain toxicity, indicating that cellular $\mathrm{K}^{+}$depletion and $\mathrm{Ca}^{2+}$ accumulation were each partially responsible for the neuronal death. Reducing $\mathrm{K}^{+}$efflux by elevating extracellular $\mathrm{K}^{+}$ from 5 to $25 \mathrm{~mm}$ also attenuated ouabain toxicity. $n=8-16$ cultures. $C$, Neither LDH release nor PI staining detected any toxicity in the pure-glia culture until the ouabain concentration reached $400 \mu \mathrm{M} . n=8-16$ cultures. Asterisks indicate a significant difference $(p<0.05)$ from the ouabain alone control $(B)$ and from the ouabain-free controls $(C)$.

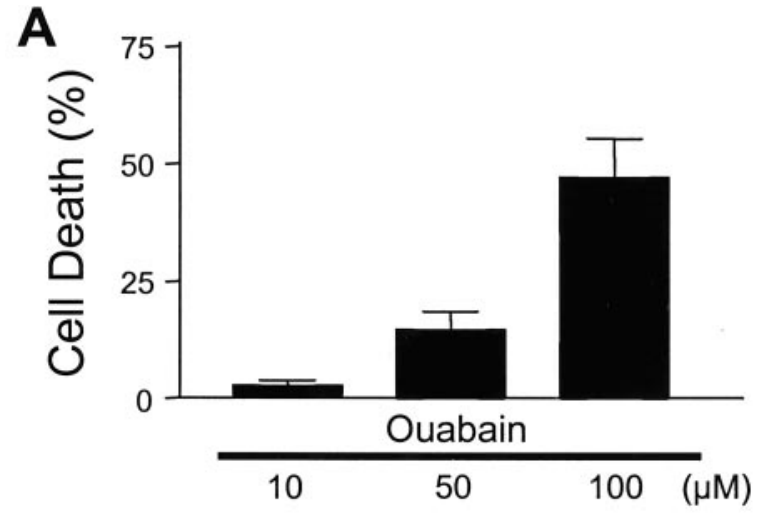

B

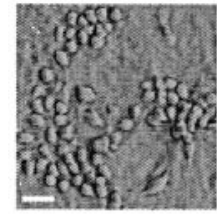

Control

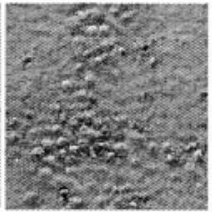

Ouabain

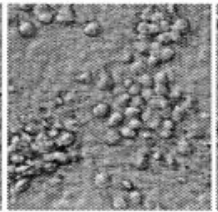

Ouabain

+ TEA

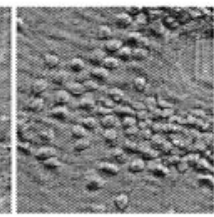

Ouabain

+ Nifedipine

+ Z-VAD-FMK
Figure 2. Ouabain induced neuronal death in neuron-glia cultures. $A$, Ouabain caused concentration-dependent neuronal death in $24 \mathrm{hr}$ in neocortical cultures containing neurons on a glial bed. Cell death was measured as LDH release and normalized to complete killing by $300 \mu \mathrm{M}$ NMDA. $B$, Phase-contrast photos of cortical cells before and after $24 \mathrm{hr}$ exposure to $80 \mu \mathrm{M}$ ouabain. Ouabain triggered widespread neuronal injury; no glial damage was detected. TEA $(30 \mathrm{~mm})$ coapplied with ouabain attenuated ouabain toxicity. Combined application of $1 \mu \mathrm{M}$ nifedipine and $100 \mu \mathrm{M}$ Z-VAD-FMK almost completely blocked ouabaininduced death. Scale bar, $50 \mu \mathrm{m}$.

Because MK-801 itself may trigger apoptotic death (Takadera et al., 1999), we verified that $1 \mu \mathrm{M}$ MK-801 alone caused little or negligible cell death after $24 \mathrm{hr}$ under our experimental condition $(\mathrm{LDH}$ release $=67 \pm 10$ and $48 \pm 10 \mathrm{U} / \mathrm{ml}$ in sham control sister cultures and MK-801-treated cultures, respectively; $n=8 ; p>$ $0.05)$. Ouabain concentrations of either 80 or $100 \mu \mathrm{M}$, which induced $40 \pm 3 \%(n=16)$ and $48 \pm 7 \%(n=16)$ neuronal death, respectively, were used in subsequent experiments.

After adding $80 \mu \mathrm{M}$ ouabain plus $1 \mu \mathrm{M}$ MK- 801 for $24 \mathrm{hr}$ and washing three times, the protein content was similar in sham and ouabain groups $(5.8 \pm 0.5$ and $6.3 \pm 0.8 \mathrm{mg} / \mathrm{ml}$, respectively; $n=$ $16 ; p>0.05$ ), so ouabain did not cause cell detachment in either pure-neuronal cultures (see above) or in neuron-glia cultures.

Cells started to swell $0.5 \mathrm{hr}$ after $80 \mu \mathrm{M}$ ouabain plus $1 \mu \mathrm{M}$ MK-801 was added, and they reached peak size in 1-2 hr (111.1 \pm $2.3 \%$ of the control cross-sectional area; $n=150$ cells; $p<0.05)$ (Fig. 3A). Cell swelling was followed by a gradual volume decrease over the next $22 \mathrm{hr}$ incubation with ouabain and MK-801; the cross-sectional area decreased by $13.7 \pm 1.8$ and $30.0 \pm 1.7 \%$, 10 and $24 \mathrm{hr}$ after ouabain exposure, respectively $(n=100$ and 150 cells; $p<0.05)$ (Fig. $3 A$ ). This cell body shrinkage suggested a possible apoptotic component to ouabain toxicity.

During ouabain incubation, there was a drastic decrease in intracellular $\mathrm{K}^{+}$content (Fig. $3 B$ ); $85 \pm 2 \%$ of cellular $\mathrm{K}^{+}$was depleted $10-15 \mathrm{hr}$ after adding $80 \mu \mathrm{M}$ ouabain (cellular $\mathrm{K}^{+}$ content was $20.4 \pm 1.4$ and $3.9 \pm 0.6 \mu \mathrm{g} / \mathrm{mg}$ protein for sham 

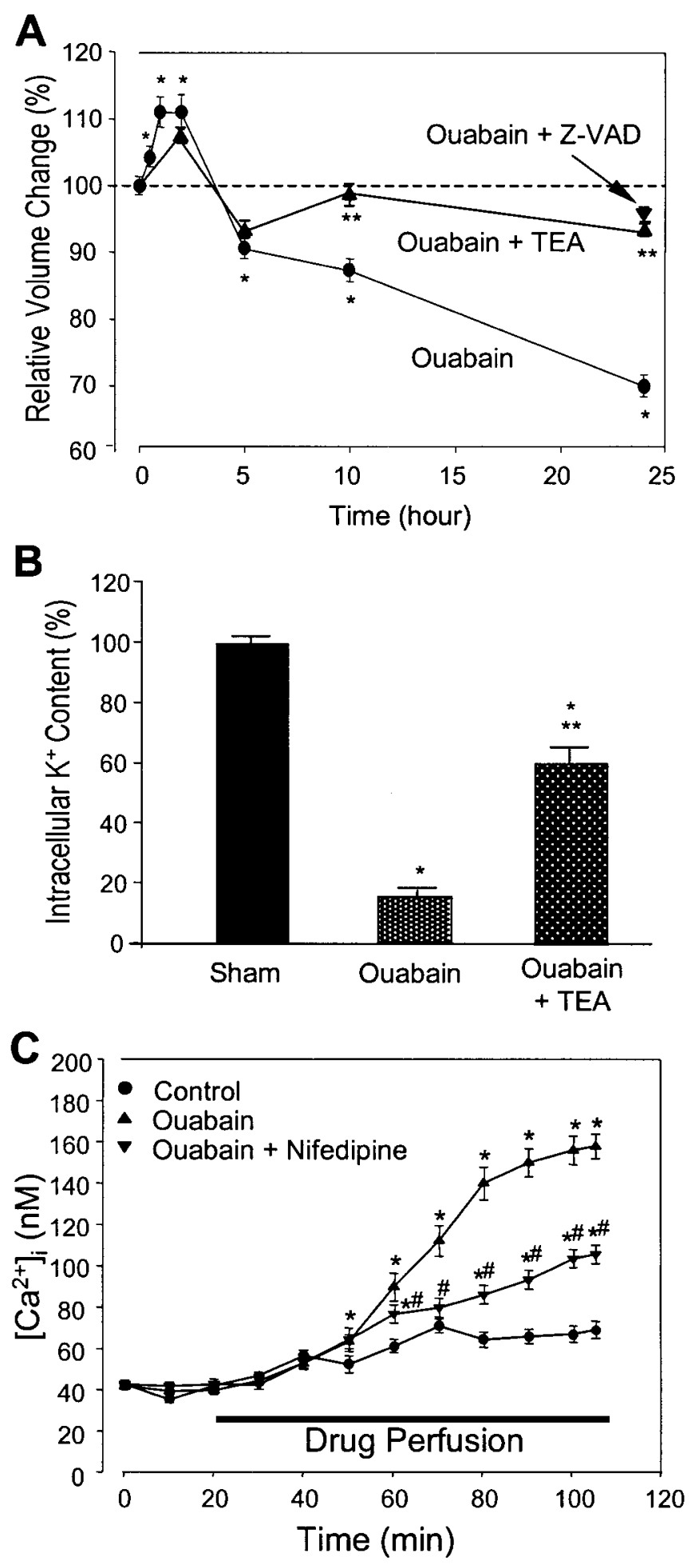

Figure 3. Ouabain-induced disruptions of ion homeostasis and cell volume changes. $A$, Ouabain treatment initiated an acute phase of cell body swelling that peaked at 1-2 $\mathrm{hr}$. Approximately $5 \mathrm{hr}$ after ouabain was added, cells started to undergo a progressive volume decrease. The cell body shrinkage was largely prevented by $30 \mathrm{~mm}$ TEA; the initial cell swelling was not affected by TEA. The ouabain-induced cell volume decrease was also prevented by the caspase inhibitor Z-VAD-FMK (100 $\mu \mathrm{M}) . n=100-150$ cells for each time point $(n=150$ for Z-VAD-FMK experiment). The single asterisks in $A$ show $p<0.05$ compared with time 0 controls. The double asterisks in $A$ show a significant difference $(p<$ $0.05)$ from the ouabain group at the same time points. $B$, Ouabain $(80 \mu \mathrm{M}$, 10-15 hr exposure) induced a massive depletion of cellular $\mathrm{K}^{+}$. The $\mathrm{K}^{+}$ control and ouabain-treated cells, respectively; $n=3$ and $4 ; p<$ 0.05). The $\mathrm{K}^{+}$channel blocker TEA (30 mM) antagonized the ouabain-induced cell volume decrease and cellular $\mathrm{K}^{+}$depletion (Figs. $2 B, 3 A, B)$. The cell shrinkage was also blocked by Z-VADFMK (Fig. $3 A$ ) and the caspase-1 inhibitor Boc-Asp(Obzl)-CMK $(\mathrm{BACMK} ; 100 \mu \mathrm{M})$ (surface area was $97.8 \pm 1.2 \%$ of controls after $10 \mathrm{hr}$ in ouabain plus BACMK; $p>005$ compared with the control volume). BACMK, however, did not prevent the ouabaininduced neuronal death after $24 \mathrm{hr}$ incubation (data not shown).

Ouabain simultaneously increased intracellular $\mathrm{Ca}^{2+}$ content by $39 \pm 16 \%\left(\mathrm{Ca}^{2+}=2.7 \pm 1.7\right.$ and $3.8 \pm 0.4 \mu \mathrm{g} / \mathrm{mg}$ protein in control and ouabain-treated cells, respectively; $n=6 ; p=0.05$ ) measured by the ICP-MS method $15 \mathrm{hr}$ after adding ouabain. Examined by Fura-2 fluorescence videomicroscopy, ouabain induced a time-dependent increase in $\left[\mathrm{Ca}^{2+}\right]_{\mathrm{i}}$. Starting at $\sim 30 \mathrm{~min}$ after exposure, the $\left[\mathrm{Ca}^{2+}\right]_{i}$ level climbed continuously until it reached a plateau level at $\sim 90 \mathrm{~min}\left(\left[\mathrm{Ca}^{2+}\right]_{\mathrm{i}}=70 \pm 4\right.$ and $157 \pm$ $6 \mathrm{~nm}$ in sham control and ouabain-treated cells, respectively) (Fig. $3 C)$. The ouabain-induced $\left[\mathrm{Ca}^{2+}\right]_{\mathrm{i}}$ increase was largely blocked by $1 \mu \mathrm{M}$ nifedipine (Fig. $3 C$ ), suggesting that the voltage-gated L-type $\mathrm{Ca}^{2+}$ channel was the major route for ouabain-induced $\mathrm{Ca}^{2+}$ influx and $\left[\mathrm{Ca}^{2+}\right]_{\mathrm{i}}$ increase. The residual $\left[\mathrm{Ca}^{2+}\right]_{\mathrm{i}}$ increase not blocked by nifedipine could be mediated by other pathways such as $\mathrm{Na}^{+}-\mathrm{Ca}^{2+}$ exchange or release from intracellular stores. As expected, ouabain incubation (10-15 hr) also increased intracellular $\mathrm{Na}^{+}$content by $58 \pm 13 \%\left(\mathrm{Na}^{+}=12.8 \pm 20.2\right.$ and $20.2 \pm 1.5 \mu \mathrm{g} / \mathrm{mg}$ protein in control and ouabain-treated cells; $n=5 ; p<0.05$; ICP-MS method). Qualitatively and quantitatively, these ouabain-induced alterations in ionic homeostasis are consistent with previous reports (Archibald and White, 1974; Lijnen et al., 1986; Ahlemeyer et al., 1992).

\section{Ouabain-induced cytochrome $c$ release, caspase activation, and ultrastructural changes}

Cytochrome $c$ release from mitochondria is a critical apoptotic event; this apoptotic process was triggered by ouabain. The ouabain-elicited cytochrome $c$ release was markedly attenuated by TEA $(30 \mathrm{~mm})$ or $25 \mathrm{~mm} \mathrm{~K}^{+}$medium but was not reduced by the $\mathrm{Ca}^{2+}$ channel antagonist nifedipine $(1 \mu \mathrm{M})$ (Fig. 4). Consistent with cytochrome $c$ release, ouabain treatment induced activation of caspase-3-like proteases. The caspase activity started rising after $15 \mathrm{hr}$ in $80 \mu \mathrm{M}$ ouabain and peaked after $24 \mathrm{hr}$ incubation (Fig. 5). Caspase-3 activation was eliminated by addition of the caspase inhibitor Z-VAD-FMK (100 $\mu \mathrm{M})$ (Fig. 5); it was also attenuated by the $\mathrm{K}^{+}$channel blocker TEA, but not by nifedipine (Fig. 5). In fact, addition of nifedipine accelerated the

\section{$\leftarrow$}

loss was attenuated by $30 \mathrm{~mm}$ TEA (Similar results were obtained by the $\mathrm{K}^{+}$-selective electrode and ICP-MS method. Shown in the figure are the results from the $\mathrm{K}^{+}$-selective electrode assay.) Ouabain also caused increases in intracellular $\mathrm{Na}^{+}$(see Results). Ouabain induced similar $\mathrm{K}^{+}$ depletion in pure-neuronal cultures (data not shown). $n=3$ measurements for time-matched sham control and TEA group; $n=6$ for ouabaintreated group. The single asterisks in $B$ show $p<0.05$ compared with the sham control. The double asterisks in $B$ show a significant difference ( $p<$ $0.05)$ from ouabain alone. $C$, Ouabain-induced $\left[\mathrm{Ca}^{2+}\right]_{\mathrm{i}}$ increase in cortical neurons. Intracellular free $\mathrm{Ca}^{2+}$ concentration was measured by fluorescence imaging with Fura-2 AM. Compared with sham control cells $(n=13)$, application of $100 \mu \mathrm{M}$ ouabain gradually increased $\left[\mathrm{Ca}^{2+}\right]_{i}$ starting at $\sim 30 \mathrm{~min}$ after ouabain was added; $\left[\mathrm{Ca}^{2+}\right]_{\mathrm{i}}$ reached a plateau level in $80-90 \mathrm{~min}(n=23)$. The ouabain-induced $\left[\mathrm{Ca}^{2+}\right]_{\mathrm{i}}$ increase was largely blocked by coapplied $1 \mu \mathrm{M}$ nifedipine $(n=28)$. MK-801 $(1 \mu \mathrm{M})$ was added in experiments. ${ }^{*} p<0.05$ compared with controls; ${ }^{\#} p<0.05$ compared with ouabain alone at the same time points. 

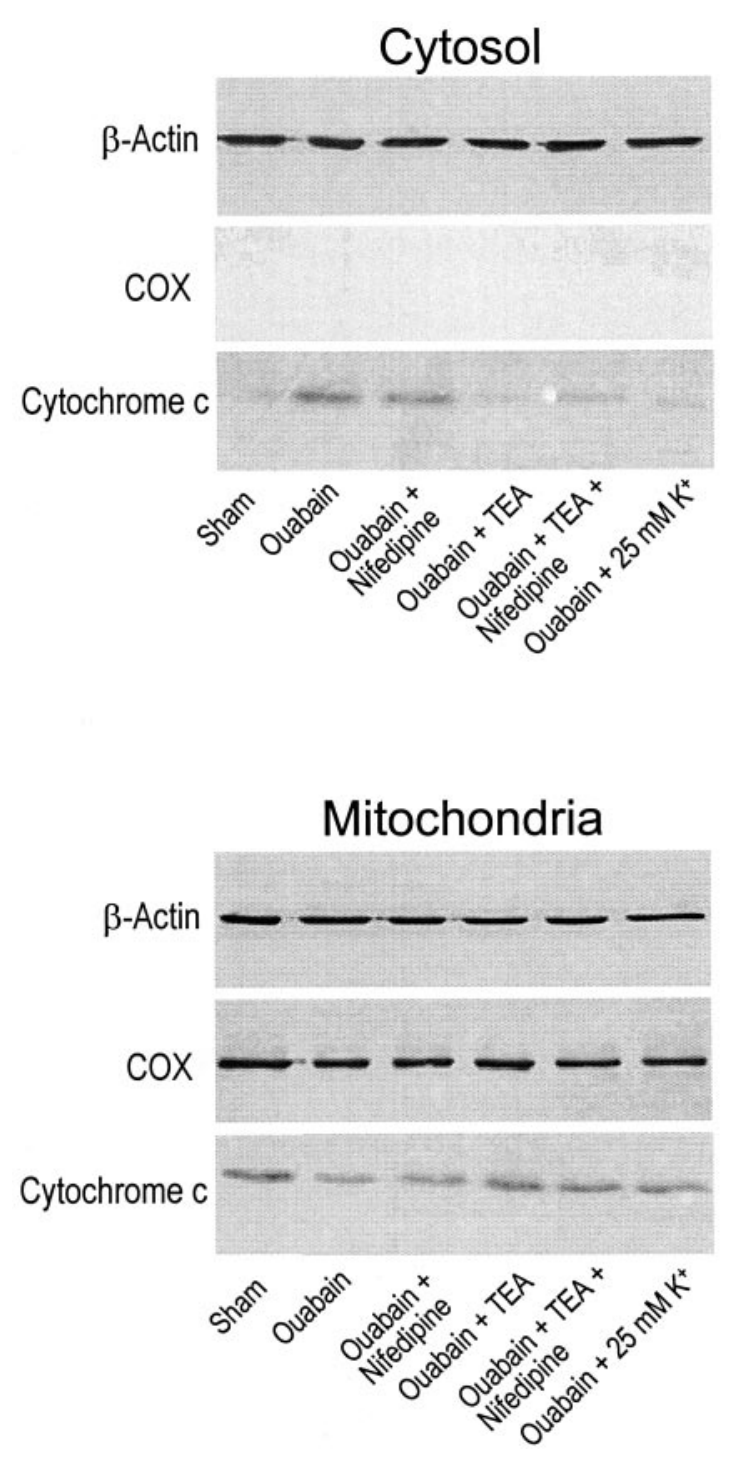

Figure 4. Effects of nifedipine, TEA, and potassium on ouabain-induced cytochrome $c$ release. Cytochrome $c$ release was detected by Western blot in the cytosolic fraction $20 \mathrm{hr}$ after incubation with $80 \mu \mathrm{M}$ ouabain (top panel), with corresponding reduction of mitochondrial cytochrome $c$ (bottom panel). Cytochrome $c$ release was drastically attenuated by TEA $(30 \mathrm{~mm})$ or elevated extracellular $\mathrm{K}^{+}\left(25 \mathrm{~mm} \mathrm{~K}^{+}\right)$; on the other hand, it was not affected by nifedipine $(1 \mu \mathrm{M})$. COX in mitochondrial fraction and its absence in cytosolic fraction demonstrated that the intact mitochondria separated from cytosol in our analysis. The $\beta$-actin analysis was performed as an internal control. The results shown are representative of three independent experiments. When nifedipine was combined with TEA, there appeared to be more cytochrome $c$ release into the cytosol compared with the release with TEA alone, suggesting that the membrane depolarization induced by TEA might facilitate the voltage-dependent block of $\mathrm{Ca}^{2+}$ channels by dihydropyridine derivatives such as nifedipine (Sanguinetti and Kass, 1984) and thus might be favorable for a low $\mathrm{Ca}^{2+}$ stimulated apoptotic process (Yu et al., 2001).

process of caspase- 3 activation by several hours, so that it peaked by $20 \mathrm{hr}$ (Fig. 5). This phenomenon and an increased cytochrome $c$ release observed when nifedipine was added together with TEA (Fig. 4) are consistent with the hypothesis that low $\left[\mathrm{Ca}^{2+}\right]_{\mathrm{i}}$ may endorse apoptosis (Yu et al., 2001). Further support for an apoptotic contribution to ouabain-induced death is the appearance of the characteristic DNA fragmentation (DNA laddering) 20-24 hr after the onset of ouabain treatment (Fig. 6). Consis-

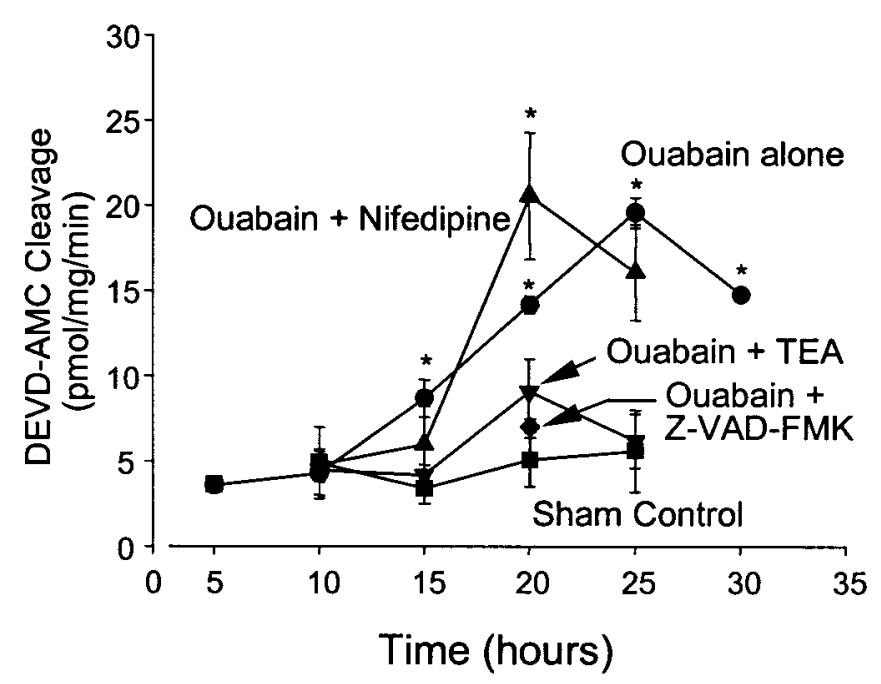

Figure 5. Effects of TEA and nifedipine on ouabain-induced caspase-3 activation. Caspase-3 activity was correlated with the cleavage of the specific substrate DEVD-AMC. In sham control experiments, caspase-3 activity was stable at a low level for $25 \mathrm{hr}(\mathbf{\square})$. Incubation with $80 \mu \mathrm{M}$ ouabain increased the caspase activity in a time-dependent manner $(\mathbf{O})$; the increase was blocked by Z-VAD-FMK $(100 \mu \mathrm{M})(\diamond)$ and TEA $(30$ $\mathrm{mM})(\boldsymbol{\nabla})$ but not by nifedipine $(1 \mu \mathrm{M})(\boldsymbol{\Delta})$. Nifedipine even appeared to accelerate the process of caspase activation. $n=3-5$ independent measurements for each time point. ${ }^{*} p<0.05$ compared with sham controls at the same time points.

tently, DNA laddering was prevented by coapplied TEA or Z-VAD-FMK, but not by nifedipine (Fig. 6).

Although all of these morphological and biochemical features are consistent with apoptosis, the caspase inhibitor Z-VADFMK, at a concentration $(100 \mu \mathrm{M})$ that completely and persistently prevented caspase-3 activation (Polverino and Patterson, 1997) (Fig. 5), blocked only $61 \pm 7 \%(n=16)$ and $65 \pm 4 \%(n=$ 44) of ouabain-induced cell death in pure-neuronal and neuronglia cultures, respectively (Figs. $1 B, 7 A$ ). The incomplete block of cell death implied that a caspase-independent component, likely necrosis, additionally contributed to ouabain toxicity.

To better characterize ouabain-induced neuronal death, electron microscopy (EM) was used to examine ultrastructural alterations. To follow the time course of morphological alterations, we examined neurons subjected to 2, 5, and $10 \mathrm{hr}$ incubation with ouabain $(100 \mu \mathrm{M})$ and MK-801 $(1 \mu \mathrm{M})$. Apoptotic changes such as nuclear condensation appeared early; meanwhile, necrotic alterations such as swelling of organelles and cytoplasm, formation of vacuoles, and disruption of membranes were also developed at early hours, suggesting that the two injurious pathways developed in parallel in ouabain toxicity (Fig. 8). After 15-20 hr exposure to ouabain, apoptotic features such as highly condensed pyknotic nuclei and dense chromatin masses were evident. Prominent necrotic features, including numerous lucent cytoplasmic vacuoles of different sizes, disruption of cellular organelles, and loss of plasma membrane integrity were also present in the same cells (Fig. 9). These mixed features of apoptosis and necrosis, referred to as hybrid death, were found in most injured cells, although there were variations in the extent of a particular change.

Consistent with the hybrid cell death mediated by separate ionic mechanisms, damaged neurons showed dominant apoptotic morphology when the $\mathrm{Ca}^{2+}$ channel antagonist nifedipine was coapplied with ouabain. On the other hand, when $\mathrm{K}^{+}$efflux was attenuated by $25 \mathrm{mM} \mathrm{K}^{+}$medium during ouabain application, EM 


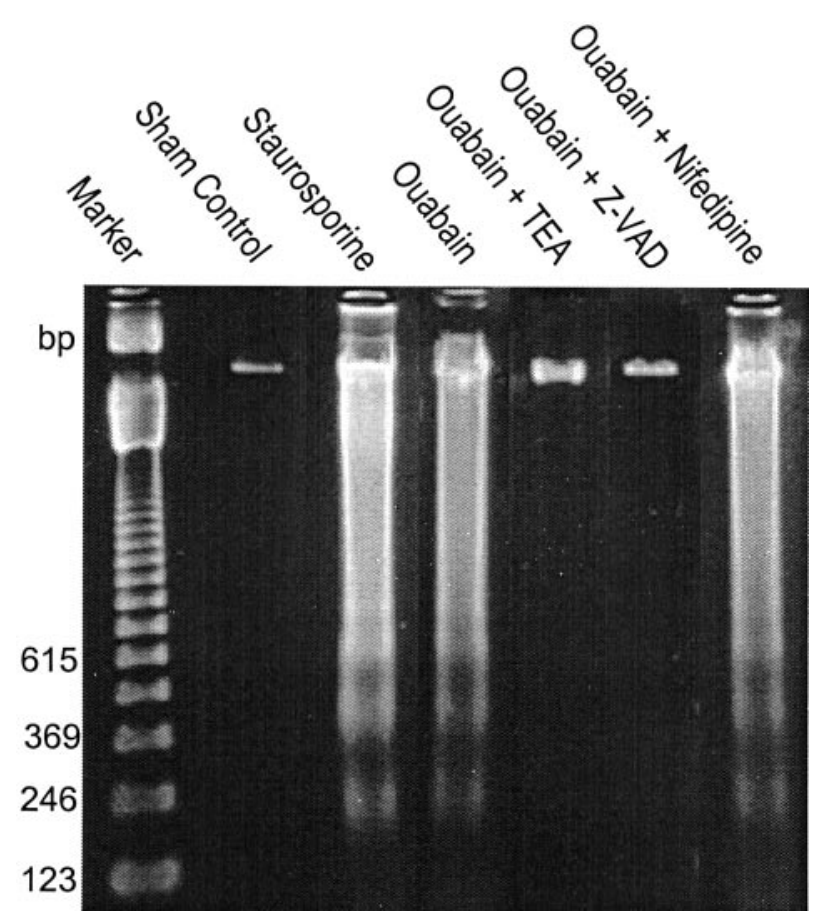

Figure 6. Ouabain-induced DNA fragmentation. Ouabain ( $80 \mu \mathrm{M})$ exposure of $20 \mathrm{hr}$ induced DNA fragmentation (laddering), revealed by agarose gel electrophoresis. The pattern of DNA damage was similar to that induced by the typical apoptosis inducer staurosporine $(0.2 \mu \mathrm{M})$. No DNA fragmentation occurred in control cells. Ouabain-induced DNA laddering was prevented by coapplied TEA $(30 \mathrm{~mm})$ or Z-VAD-FMK $(100 \mu \mathrm{M})$, but not by nifedipine $(1 \mu \mathrm{M})$. Similar results were obtained from three independent experiments. Data shown in the figure were from one experiment; the position of columns was rearranged for purpose of clarity.

examination revealed typical necrotic alterations in most cells (Fig. 9).

\section{lonic mechanisms underlying ouabain-induced hybrid cell death}

Cellular $\mathrm{K}^{+}$homeostasis is maintained by $\mathrm{K}^{+}$efflux and $\mathrm{K}^{+}$ uptake mechanisms. In the presence of MK-801, the major pathway for $\mathrm{K}^{+}$efflux from neurons is the family of the TEA-sensitive, noninactivating delayed rectifier $I_{\mathrm{K}}$ channels, whereas the $\mathrm{Na}^{+}$, $\mathrm{K}^{+}$-ATPase is responsible for moving $\mathrm{K}^{+}$back into the cell from the extracellular space. We reasoned and demonstrated above that as long as $\mathrm{K}^{+}$efflux was prevented throughout the ouabain treatment, there would be no marked cellular $\mathrm{K}^{+}$loss even if the $\mathrm{Na}^{+}, \mathrm{K}^{+}$-pump were blocked. Therefore, should $\mathrm{K}^{+}$efflux and cellular $\mathrm{K}^{+}$depletion be key steps in apoptosis, blocking $\mathrm{K}^{+}$ channels would be able to attenuate ouabain-induced cell death. As expected, the $\mathrm{K}^{+}$channel blocker TEA (30 mM) or tetrapentylammonium (TPeA; $10 \mu \mathrm{M})$ significantly reduced ouabaininduced cell death $(28.9 \pm 4.3$ and $65.4 \pm 6.5 \%$ reduction for the TEA and TPeA groups, respectively) (Fig. $7 B$ ). Consistent with this finding, ouabain induced much less cell death (43\% reduction; $n=28$ ) in $25 \mathrm{~mm} \mathrm{~K}^{+}$medium than in the control medium of $5 \mathrm{~mm} \mathrm{~K}^{+}$(Fig. $7 C$ ).

To verify the involvement of $\mathrm{Na}^{+}, \mathrm{K}^{+}$-ATPase in neurotoxicity, we tested another selective $\mathrm{Na}^{+}$pump inhibitor, strophanthidin (Balzan et al., 2000). Strophanthidin $(800 \mu \mathrm{M})$ induced $\sim 40 \%$ neuronal death in $24 \mathrm{hr}$; the cell injury measured by LDH release was reduced from $273 \mathrm{U} / \mathrm{ml}$ to $160 \mathrm{U} / \mathrm{ml}(41 \pm 1 \%$ reduction; $n=$ $8 ; p<0.05)$ by $100 \mu \mathrm{M}$ Z-VAD-FMK, and to $217 \mathrm{U} / \mathrm{ml}$ by $25 \mathrm{~mm}$ extracellular $\mathrm{K}^{+}(21 \pm 1 \%$ reduction; $n=8 ; p<0.05)$, respectively. These results confirmed that $\mathrm{Na}^{+}$pump failure caused a $\mathrm{K}^{+}$efflux-related and caspase-dependent apoptotic injury.

Because inhibition of $\mathrm{Na}^{+}, \mathrm{K}^{+}$-ATPase increased intracellular $\mathrm{Ca}^{2+}$ and $\mathrm{Na}^{+}$, and EM assay revealed a necrotic component in ouabain-induced cell death, we tested the idea that $\mathrm{Ca}^{2+}$ or $\mathrm{Na}^{+}$ channel blockers might selectively attenuate the necrotic injury of ouabain toxicity. A combination of $80 \mu \mathrm{M}$ ouabain and the $\mathrm{Ca}^{2+}$ channel antagonist nifedipine $(1 \mu \mathrm{M} ; n=23)$ or $\mathrm{Na}^{+}$channel blocker tetradotoxin (TTX) $(1 \mu \mathrm{M} ; n=8)$ reduced ouabaininduced cell death by $43 \pm 8$ and $32 \pm 5 \%$, respectively (Fig. $7 D$ ). We then compared the protective effects of these channel blockers alone and in combination with Z-VAD-FMK. Virtually complete protection was achieved when nifedipine was coapplied with Z-VAD-FMK (Figs. 2B, 7D). Combined application of TTX and Z-VAD-FMK also brought out additional neuroprotection (Fig. $7 D$ ), suggesting a role for $\mathrm{Na}^{+}$influx, although less imperative than $\mathrm{Ca}^{2+}$ influx, in necrotic death. Combination of TEA or 25 $\mathrm{mM} \mathrm{K}^{+}$with nifedipine did not produce full protection, in line with the incomplete block of $\mathrm{K}^{+}$depletion and some residual caspase-3 activity in the presence of TEA (Figs. 3B, 5). In agreement with this, Z-VAD-FMK enhanced the protective effect of 30 mM TEA (Fig. 7B). Higher concentrations of TEA were toxic and not tested further.

Young cells are more vulnerable to apoptosis. For example, staurosporine induced no appreciable apoptosis in cultured cortical neurons older than 16-17 DIV (Koh et al., 1995), which is consistent with the lack of upmodulation of $I_{\mathrm{K}}$ current in these cells (Yu et al., 1997). However, older cortical neurons (16 DIV) exhibited even higher vulnerability to ouabain toxicity; $80 \mu \mathrm{M}$ ouabain, in the presence of $1 \mu \mathrm{M}$ MK-801, triggered $75 \%$ neuronal death in these cells compared with $\pm 40 \%$ death in $11-12$ DIV neurons. This enhanced toxicity was unlikely caused by MK-801; the putative pro-apoptotic effect of MK-801 diminishes in cortical neurons older than 12 DIV (Kim-Han et al., 1999). The death in 16 DIV cultures was reduced by approximately one-half by Z-VAD-FMF (100 $\mu \mathrm{M})$, TEA (30 mM), elevated extracellular $\mathrm{K}^{+}$ $\left(25 \mathrm{mM} \mathrm{K}^{+}\right)$, or nifedipine $(1 \mu \mathrm{M})(n=12$ for each treatment; $p<$ 0.05 compared with sham controls). Therefore, ouabain triggered ionic disruption and accordant hybrid death in young and old neurons.

\section{Ouabain-induced death in low $\mathrm{Ca}^{2+}$, low $\mathrm{Na}^{+}$conditions}

In the ischemic brain, extracellular $\mathrm{Ca}^{2+}$ and $\mathrm{Na}^{+}$concentrations decline to levels as low as 0.1 and $30-50 \mathrm{~mm}$, respectively (Siesjo, 1992; Xie et al., 1994; Kristian and Siesjo, 1996). We suspected that under such conditions, in conjunction with insufficient energy supply, apoptosis might become the dominant form of neuronal death. To model this pathological condition, we tested the effect of ouabain in a low $\mathrm{Ca}^{2+}\left(0.1\right.$ vs $\left.1.5 \mathrm{~mm} \mathrm{CaCl}_{2}\right)$ or low $\mathrm{Na}^{+}(60$ vs $120 \mathrm{~mm} \mathrm{NaCl})$ medium. Osmolarity was adjusted by adding $N$-methyl-D-glucamine and $\mathrm{HCl}$ to the medium, $\mathrm{pH}$ 7.4. Incubation for 3-5 hr with this medium alone did not reduce cell viability $24 \mathrm{hr}$ after the onset of incubation. Adding $80 \mu \mathrm{M}$ ouabain during the few hours of incubation, however, caused significant $(\sim 50 \%)$ neuronal death in $24 \mathrm{hr}$. Most of the cell death was blocked by Z-VAD-FMK, suggesting apoptosis-dominated death under these conditions (Fig. 10). Consistent with this, reducing $\mathrm{K}^{+}$efflux by raising the extracellular $\mathrm{K}^{+}$concentration blocked $\sim 80 \%$ of the cell death in either medium (Fig. 10). Nifedipine, added to the low $\mathrm{Ca}^{2+} /$ high $\mathrm{K}^{+}$ 

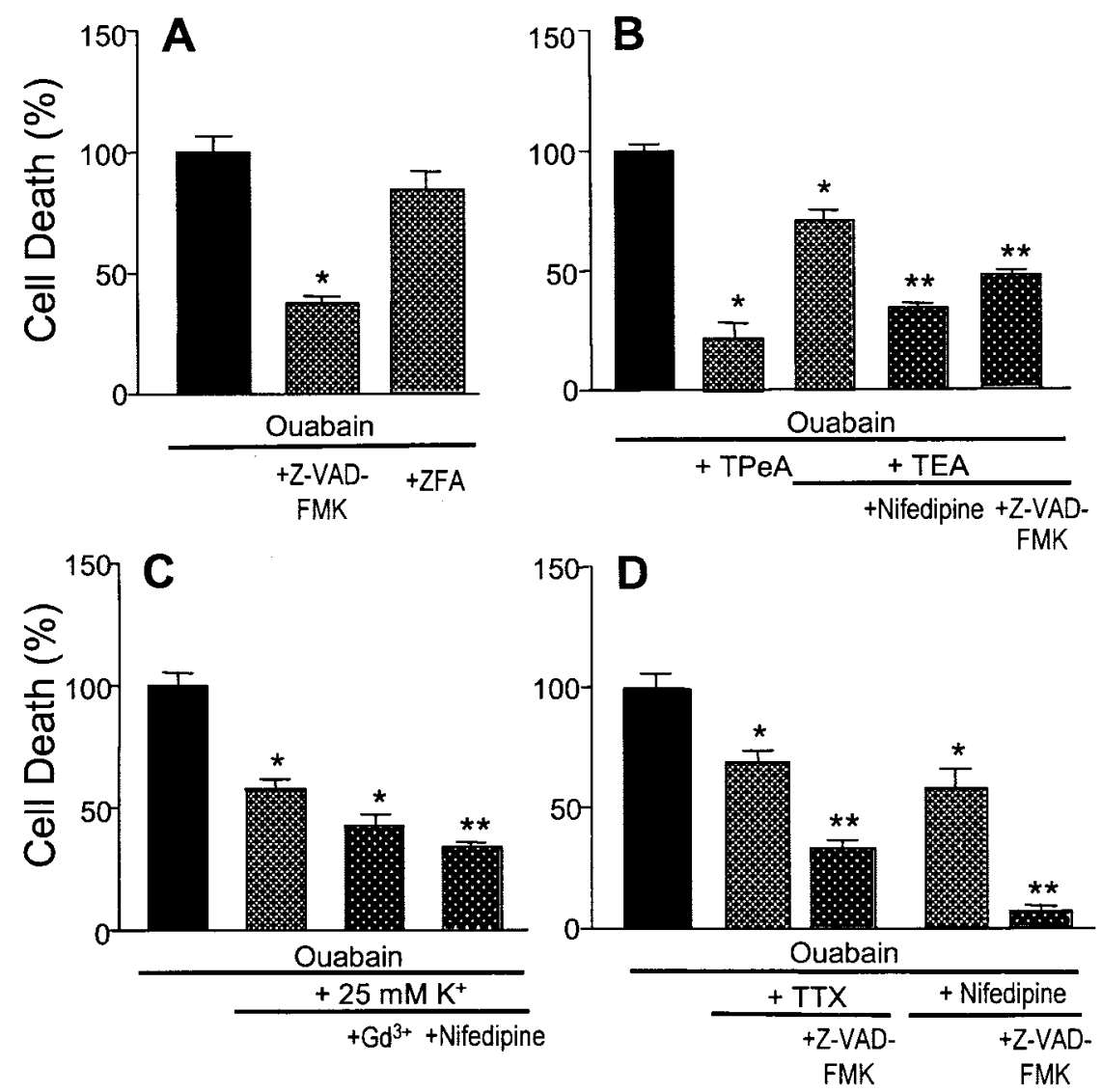

Figure 7. Block of ouabain-induced cell death in cortical neuron-glia cultures. Ouabain-induced neuronal death in cortical cultures containing neurons and a glial bed was measured by LDH release after 24 hr exposure and normalized to the cell death induced by $80 \mu \mathrm{M}$ ouabain. $A$, The broad-spectrum caspase inhibitor Z-VAD-FMK $(100 \mu \mathrm{M})$ blocked $65 \pm 4 \%$ of cell death, whereas its negative control ZFA $(100 \mu \mathrm{M})$ showed no significant protection $(p=0.16)$. $B$, Potassium channel blocker TEA (30 mM) or TPeA $(10 \mu \mathrm{M})$ partly reduced the ouabain-induced neuronal death; coapplied $1 \mu \mathrm{M}$ nifedipine or $100 \mu \mathrm{M}$ Z-VAD-FMK provided extra protection. TPeA showed substantial protection, presumably because of its additional nonspecific block on $\mathrm{Ca}^{2+}$ channels (Wang et al., 2000). $C$, Elevated extracellular $\mathrm{K}^{+}(25 \mathrm{~mm} \mathrm{KCl})$ attenuated ouabain-induced death; additional protection was obtained with coapplied $\mathrm{Ca}^{2+}$ channel antagonist $2 \mu \mathrm{M}$ gadolinium $\left(\mathrm{Gd}^{3+}\right)$ or $1 \mu \mathrm{M}$ nifedipine. $D$, Nifedipine $(1 \mu \mathrm{M})$ or the $\mathrm{Na}^{+}$channel blocker TTX $(1 \mu \mathrm{M})$ also partially prevented the ouabain toxicity. Maximal neuroprotection was achieved by combining nifedipine with Z-VAD-FMK. $n \geq 12$ for each column except for ZFA and TTX $(n=8) .{ }^{*} p<0.05$ compared with ouabain alone; $* * p<0.05$ compared with ouabain plus one treatment. medium, provided no additional protection, consistent with the already reduced $\mathrm{Ca}^{2+}$ influx. Under these conditions, TTX further promoted cell survival by blocking $\mathrm{Na}^{+}$influx (Fig. 10). Nifedipine provided extra protection in the low $\mathrm{Na}^{+} /$normal $\mathrm{Ca}^{2+}$ medium, where $\mathrm{Ca}^{2+}$ influx might still normally occur (Fig. 10).

\section{DISCUSSION}

Collective evidence agrees that blocking $\mathrm{Na}^{+}, \mathrm{K}^{+}$-ATPase induces a mixed neuronal death with features of both apoptosis and necrosis. The caspase-mediated apoptotic component is associated with $\mathrm{K}^{+}$channel activation, $\mathrm{K}^{+}$efflux, and cellular $\mathrm{K}^{+}$loss, whereas the nifedipine-blocked $\mathrm{Ca}^{2+}$-associated cell injury is caspase independent. In this context, the protective effect of blocking $\mathrm{Na}^{+}$channels may be mediated indirectly by reducing the reversed $\mathrm{Na}^{+}-\mathrm{Ca}^{2+}$ exchange activity, thereby preventing a secondary $\left[\mathrm{Ca}^{2+}\right]_{\mathrm{i}}$ increase. Although ouabain-induced apoptosis has been reported in a few previous studies (Olej et al., 1998; Verheye-Dua and Bohm, 2000), this investigation provides the first evidence of a mixed death in ouabain toxicity. Despite the emerging idea of an overlap of necrosis and apoptosis in tissues and cell cultures (Toescu 1998), current popular opinion associates these different processes with separate subgroups of cells or consecutive events (e.g., necrosis followed by apoptosis) (Lipton and Nicotera 1998) (Fig. 11). The present study establishes the concept and a model of hybrid death as concurrent necrosis and apoptosis in single cells throughout the death process (Fig. 11).

The $\mathrm{Na}^{+}, \mathrm{K}^{+}$-ATPase is present in all mammalian cells. The activity of $\mathrm{Na}^{+}, \mathrm{K}^{+}$-ATPase in brain cortical glial cells should have a significant impact on the microenvironment surrounding neurons and their ionic homeostasis. Glial cells express $\alpha 1$ and $\alpha 2$ isoforms of $\mathrm{Na}^{+}, \mathrm{K}^{+}$-ATPase; the lack of the $\alpha 3$ isoform of high ouabain affinity explains the low ouabain toxicity in glial cultures (McGrail et al., 1991; Watts et al., 1991). Although our experiments using mixed cultures do not completely exclude interference from glial cells, it is unlikely that glia have much effect on the nature of hybrid injuries.

The digitalis glycoside, ouabain, has endogenous analogs with intrinsic regulatory properties in vertebrate physiology (Budzikowski et al., 1998; Ferrandi and Manunta, 2000). In rats and humans, "endogenous ouabain" has been detected in all tissues tested (Hamlyn et al., 1996). The level of endogenous ouabain in circulation increases on exposure to stress signals such as hypertension and hypoxia/ischemia (Bagrov et al., 1994; De Angelis and Haupert, 1998; Ferrandi and Manunta, 2000). Accordingly, the $\mathrm{Na}^{+}, \mathrm{K}^{+}$-ATPase activity in the ischemic heart, brain, and other organs decreases (Lees, 1991; Bundgaard et al., 1997). Ouabain sensitized human and rodent tumor cells to tumor necrosis factor (TNF)-induced apoptosis (Penning et al., 2000), enhanced irradiation-induced apoptosis in human cell lines of defined tumor protein p53 status (Verheye-Dua and Bohm, 2000), and potentiated anti-Fas-induced apoptosis (Bortner et al., 2001). Thus $\mathrm{Na}^{+}, \mathrm{K}^{+}$-ATPase plays an imperative role in apoptosis induced by different insults in different cells.

We and others have shown that excessive $\mathrm{K}^{+}$efflux mediated by $\mathrm{K}^{+}$channels or NMDA receptor channels is a key event in the apoptotic cascade (Yu et al., 1997, 1999a; Colom et al., 1998; Wang et al., 1999; Krick et al. 2001). Cellular $\mathrm{K}^{+}$depletion is likely a prerequisite for activation of two apoptotic mediators: caspases and endonucleases (Dallaporta et al., 1999; Hughes and Cidlowski, 1999; Yu et al., 1999b; Wang et al., 2000). In the experiment with pure-neuronal cultures, 10-15 hr ouabain incu- 

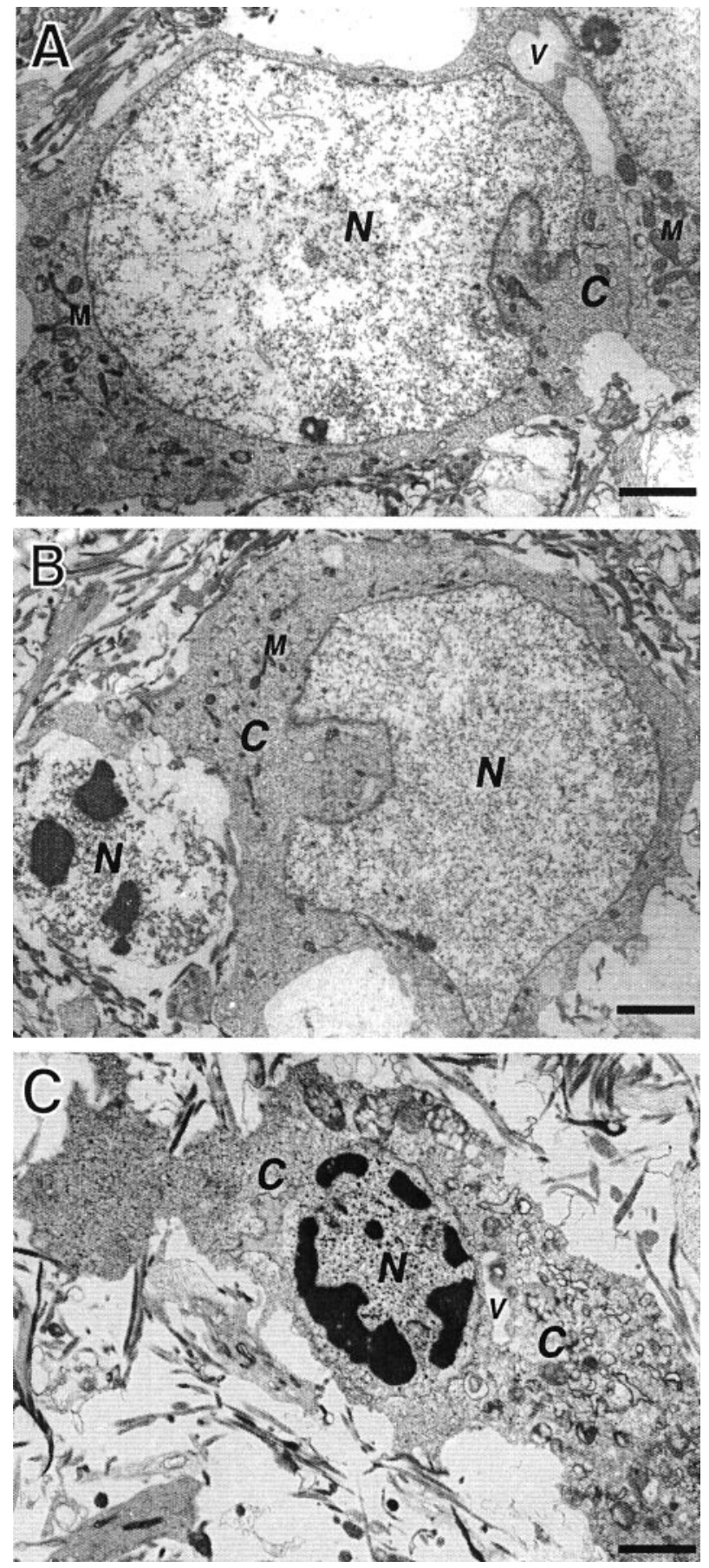

Figure 8. Morphological changes of hybrid cell death at early time points of ouabain exposure. EM images reveal ouabain-induced ultrastructural alterations in cortical neurons; morphology of a normal neuron can be seen in Figure 9. $A$, Two hours after adding $100 \mu \mathrm{M}$ ouabain plus $1 \mu \mathrm{M}$ MK-801, some cells started to show signs of nuclear changes; the electron micrograph shows an irregular shape of the nucleus, implying a volume decrease. Meanwhile, swelling mitochondria were observed in many cells. $B$, Apoptotic features such as nuclear shrinkage and condensation of the nuclear chromatin were advanced after $5 \mathrm{hr}$ in ouabain. Necrotic changes such as cytoplasm swelling, formation of vacuoles, and disruptions of cellular organelles and the plasma membrane also appeared at earlier hours. The two cells shown in this micrograph represent different stages of morphological changes observed at this time. $C$, Ten hours after onset of ouabain exposure, injured cells with highly condensed nuclei, chaotic cytoplasm, and disrupted plasma membrane were easily detected. Scale bar, $3.0 \mu \mathrm{m}$. $N$, Nucleus; $C$, cytoplasm; $M$, mitochondria; $V$, vacuole. bation induced an $11 \%$ volume decrease, whereas cells lost $72 \%$ of their $\mathrm{K}^{+}$, implying that intracellular $\mathrm{K}^{+}$concentration was likely decreased by $\sim 61 \%$. Presuming that resting intracellular $\mathrm{K}^{+}$concentration is $140 \mathrm{~mm}$ and acts as the predominant element for cell volume regulation and that water loss is proportional to the volume loss, the $\mathrm{K}^{+}$concentration would be reduced to $\sim 55$ $\mathrm{mm}$ by the ouabain treatment, consistent with the values $(50-56$ $\mathrm{mm}$ ) reported by others in cells undergoing apoptosis (Barbiero et al., 1995; Hughes et al., 1997).

Blocking $\mathrm{K}^{+}$efflux prevented cytochrome $c$ release, caspase-3 activation, and DNA laddering, placing cellular $\mathrm{K}^{+}$loss before these apoptotic steps. It reinforces the notion that $\mathrm{K}^{+}$acts as an endogenous modulator of several checkpoints (e.g., cytochrome $c$ release, caspase cleavage, and endonuclease activation) in the apoptotic cascade. Recent progress suggests that programmed cell death such as that induced by apoptosis-inducing factor (AIF) may be independent of Apaf-1, cytochrome $c$, and caspases (Joza et al., 2001). Interestingly, the endonuclease activation and DNA damage in AIF-induced programmed death are still $\mathrm{K}^{+}$ dependent (Dallaporta et al., 1998), suggesting that the $\mathrm{K}^{+}$mechanism may control different forms of programmed death that contribute to the hybrid cell death. A nonapoptotic programmed cell death induced by expression of insulin-like growth factor I receptor was reported recently (Sperandio et al., 2000). This type of cell death, although related to caspase- 9 activation and protein synthesis, lacks almost all morphological features of apoptosis, suggesting that it is not linked to cellular $\mathrm{K}^{+}$depletion and may be a distinct form of cell death different from the hybrid death observed in this study.

The major anti-apoptotic members of the Bcl-2 family, Bcl-2 or $\mathrm{Bcl}_{\mathrm{x} 1}$, show protective effects against apoptosis induced by blocking the $\mathrm{Na}^{+}, \mathrm{K}^{+}$-pump (Gilbert and Knox, 1997; Kawazoe et al., 1999), presumably because of an enhanced pump activity and maintaining sufficient mitochondrial ATP/ADP exchange to sustain coupled respiration (Gilbert and Knox, 1997; Vander Heiden et al., 1999). Thus, the Bcl-2 family may have a significant influence on apoptosis as well as the mixed form of cell death. Because the $\mathrm{K}^{+}$mechanism has been demonstrated in apoptosis induced by receptor and nonreceptor associated insults (Hughes and $\mathrm{Ci}$ dlowski, 1999; Penning et al., 2000; Bortner et al., 2001), it is conceivable that the apoptotic components associated with either cytochrome $c /$ caspase- 3 cascade or "death receptors," such as the TNF- $\alpha$ pathway, may both be able to intervene in hybrid cell death.

The broad-spectrum caspase-inhibitor Z-VAD-FMK prevented the ouabain-induced cell volume decrease, in agreement with observations of some groups (Choi et al. 2000; Lang et al., 2000; Nobel et al., 2000) but in contrast to results from others (Maeno et al., 2000; Yu and Choi, 2000). This discrepancy may imply a role for specific caspases, but not caspase-3 (see below), in cell volume regulation. For example, the apoptotic cell shrinkage induced by etoposide or methylprednisolone is blocked by caspase-1 inhibitors in thymocytes (Zhivotovsky et al., 1995). Because casapase-1 activity is relatively uninfluenced by $\mathrm{K}^{+}$ (Hughes et al., 1997; Yu et al., 1999b), its activation may occur in the absence of excessive $\mathrm{K}^{+}$efflux and cell shrinkage. Our data with the caspase- 1 inhibitor BACMK suggest that this particular caspase may be activated early and plays an important role in neuronal apoptotic shrinkage. On the other hand, caspase-3 activation is a relatively delayed event ( $15 \mathrm{hr}$ later), after cellular $\mathrm{K}^{+}$depletion and cell shrinkage but still before the cell death measured by $\mathrm{LDH}$ release. Surprisingly, BACMK did not show 


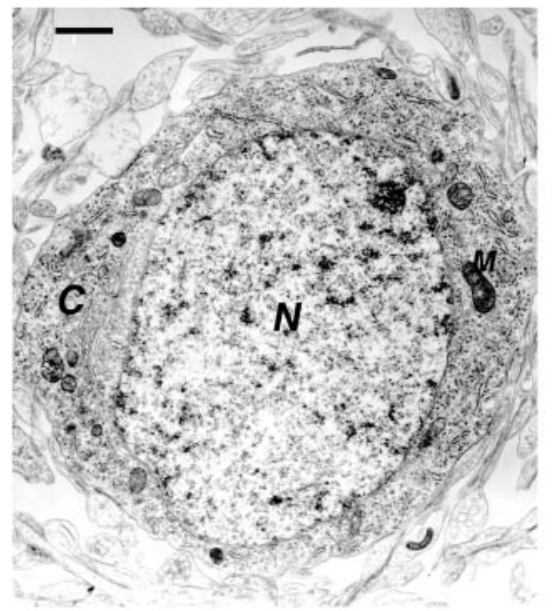

Sham Control

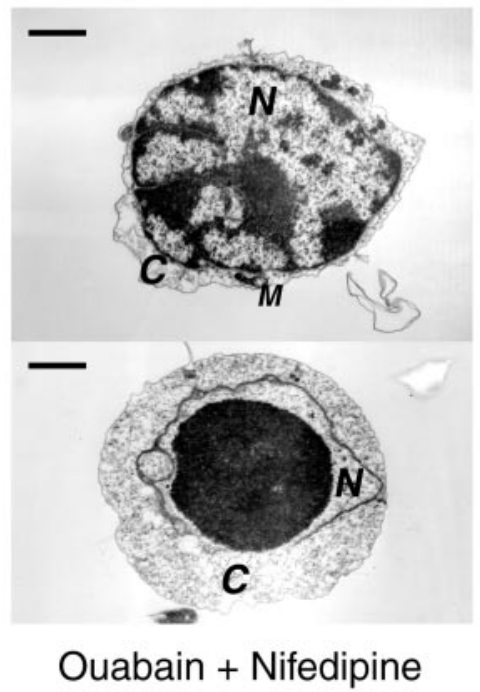

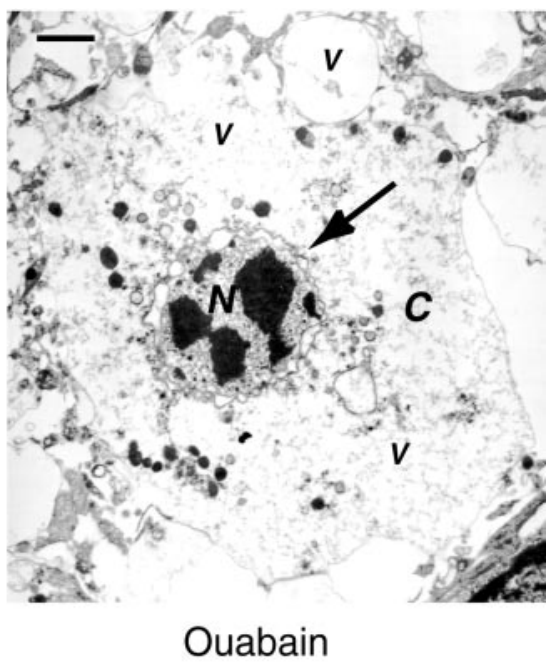

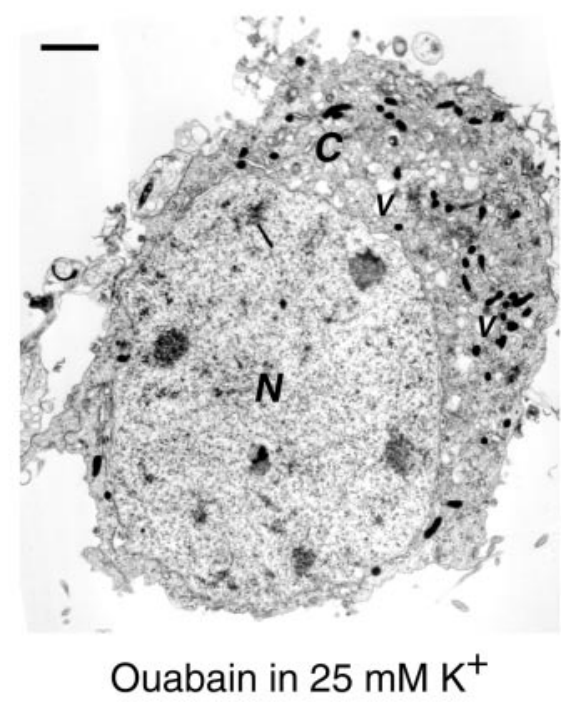

Figure 9. Ouabain-induced ultrastructural alterations and effects of nifedipine and high $\mathrm{K}^{+}$medium. Electron micrographs show a control neuron and reveal striking morphological distinctions after different treatments. The normal cortical neuron has a relatively small cytoplasm and a large nucleus; the cell and cellular organelles are surrounded by intact membranes. Approximately $15 \mathrm{hr}$ after incubation in 100 $\mu \mathrm{M}$ ouabain and $1 \mu \mathrm{M}$ MK-801, injured cells show apoptotic features such as highly condensed nuclei and dark chromatin clumps (arrow) accompanied by necrotic changes, including cytoplasmic edema manifested by vacuolization and decreased cytoplasmic density, loss of cellular organelles, and breakdown of the plasma membrane. In another experiment, the $\mathrm{Ca}^{2+}$ channel antagonist nifedipine $(1 \mu \mathrm{M})$, coapplied with ouabain, mostly eliminated necrotic alterations. Two representative injured cells show typical apoptotic morphology, including highly condensed nuclei and cytoplasm, dark chromatin masses (pyknosis) with or without fragmentation, intact cellular organelles, and intact plasma membrane. Reducing $\mathrm{K}^{+}$efflux, on the other hand, by raising extracellular $\mathrm{K}^{+}$to $25 \mathrm{~mm}$ resulted in the morphological pattern of necrotic injury in most cells. A representative cell shows that ouabain in the high $\mathrm{K}^{+}$medium induced chaotic alterations in the swollen cytoplasm. No single intact cellular organelle can be detected in the cell; instead, lucent vacuoles appear in the cytoplasm. The cell membrane is deteriorating, but there is little or no nuclear/cellular shrinkage and no chromatin condensation or fragmentation. Scale bars, $2.0 \mu \mathrm{m}$. $N$, Nucleus; $C$, cytoplasm; $M$, mitochondria; $V$, vacuole. any neuroprotective effect against ouabain toxicity. The explanation for the dissociation of BACMK action on cell volume and cell death is obscure and deserves future investigation.

Increases in $\left[\mathrm{Ca}^{2+}\right]_{\mathrm{i}}$ may trigger apoptosis (Lipton and Nicotera 1998; Toescu 1998). In the present study, blocking of $\mathrm{Ca}^{2+}$ influx and $\left[\mathrm{Ca}^{2+}\right]_{\mathrm{i}}$ increase did not inhibit cytochrome $c$ release or caspase-3 activation, suggesting that the ouabain-induced $\left[\mathrm{Ca}^{2+}\right]_{\mathrm{i}}$ increase did not play a primary role in induction of apoptosis. On the other hand, an increase in $\left[\mathrm{Ca}^{2+}\right]_{i}$ may explain protection against apoptosis in sympathetic ganglia and cerebellar granule neurons (Johnson et al., 1992). Blocking $\mathrm{Ca}^{2+}$ entry and $\left[\mathrm{Ca}^{2+}\right]_{\mathrm{i}}$ increase, however, did not eliminate the antiapoptotic effect of elevated extracellular $\mathrm{K}^{+}$or $\mathrm{K}^{+}$channel blockers in cortical neurons (Yu et al., 1997). The discrepancy may be attributable to the fact that apoptosis can be mediated by multiple pathways and that apoptotic mechanisms differ by cell types. For example, in M1 myeloid leukemia cells, $\mathrm{Ca}^{2+}$ mobilizing compounds like the $\mathrm{Ca}^{2+}$ ionophore $\mathrm{A} 23187$ and the endoplasmic reticulum $\mathrm{Ca}^{2+}$-ATPase inhibitor thapsigargin can either suppress or induce apoptosis, depending on activation of different signal transduction pathways (Lotem et al., 1999). In cerebellar granule cells and vascular smooth muscle, the $\mathrm{Na}^{+} / \mathrm{K}^{+}$ ratio, rather than $\mathrm{K}^{+}$concentration or ionic strength, was pro- posed to determine the outcome of an apoptotic insult (Isaev et al., 2000; Orlov et al., 2000).

Although apoptosis and necrosis are two separate fundamental aspects of cell death, the most recent findings suggest that cell death often falls somewhere between the two extremes in the spectrum. Cell death bearing both apoptotic and necrotic features can be induced by glutamate, zinc, or oxygen-glucose deprivation in mouse cortical neurons (Gwag et al., 1995; Cheung et al., 1998; Sohn et al., 1998; Kim et al., 1999) and by other insults in various cells (Papadimitriou et al., 1994; Tsujimoto et al., 1997; Villalba et al., 1997; Okuno et al., 1998; Miller et al., 2000; Park et al., 2000). Features of mixed death may also be found in a number of other studies (Molthagen et al., 1996; Warny and Kelly, 1999), including those of myocardial cells after coronary artery occlusion and reperfusion in vivo (Takashi and Ashraf, 2000) and in the adult or newborn rat brain (Portera-Cailliau et al., 1997). After hypoxic ischemia in the newborn rat, "hybrid" neuronal cells with intermediate ultrastructural characteristics similar to the mixed death shown in this study were observed (Nakajima et al., 2000). Accumulating evidence, therefore, demonstrates that mixed or hybrid cell death is common either in vitro or in vivo under different pathological conditions.

Rather than debating whether atypical cell death with mixed 
Figure 10. Ouabain-induced $\mathrm{K}^{+}$efflux-sensitive and caspase-dependent neuronal death in low $\mathrm{Ca}^{2+}$ or low $\mathrm{Na}^{+}$conditions. A $3 \mathrm{hr}$ exposure to 80 $\mu \mathrm{M}$ ouabain plus $1 \mu \mathrm{M}$ MK-801 in a low $\mathrm{Ca}^{2+}(0.1$ $\left.\mathrm{mm} \mathrm{CaCl})_{2}\right)$ or a low $\mathrm{Na}^{+}(60 \mathrm{~mm} \mathrm{NaCl})$ medium induced a dominant neuronal death that was highly sensitive to block by $25 \mathrm{~mm} \mathrm{~K}{ }^{+}$or Z-VAD-FMK $(100 \mu \mathrm{M})$. Without ouabain, the low $\mathrm{Ca}^{2+}$ or low $\mathrm{Na}^{+}$medium was not toxic ( $3 \mathrm{hr}$ exposure; data not shown). In the low $\mathrm{Ca}^{2+}$ medium containing a normal concentration of $\mathrm{Na}^{+}$, the $\mathrm{Ca}^{2+}$ channel antagonist nifedipine $(1 \mu \mathrm{M})$ did not show any effect on the neuroprotection produced by elevated $\mathrm{K}^{+}$, whereas combination of high $\mathrm{K}^{+}$and the $\mathrm{Na}^{+}$ channel blocker TTX $(1 \mu \mathrm{M})$ completely prevented cell death. In the low- $\mathrm{Na}^{+}$medium containing normal $\mathrm{Ca}^{2+}$, an additional protective effect was obtained by combining high $\mathrm{K}^{+}$and nifedipine (TTX was not tested in this paradigm). Cell death is normalized to the injury induced by $80 \mu \mathrm{M}$ ouabain in medium containing normal concentrations of $\mathrm{CaCl}_{2}(1.5 \mathrm{~mm})$ and $\mathrm{NaCl}(120 \mathrm{~mm})(\mathrm{MEM}$ supplemented with glucose, FBS, HS, and EGF; see Materials and Methods). This medium was used to wash out ouabain after the $3 \mathrm{hr}$ incubation. Cell death was measured by LDH release $24 \mathrm{hr}$ after the

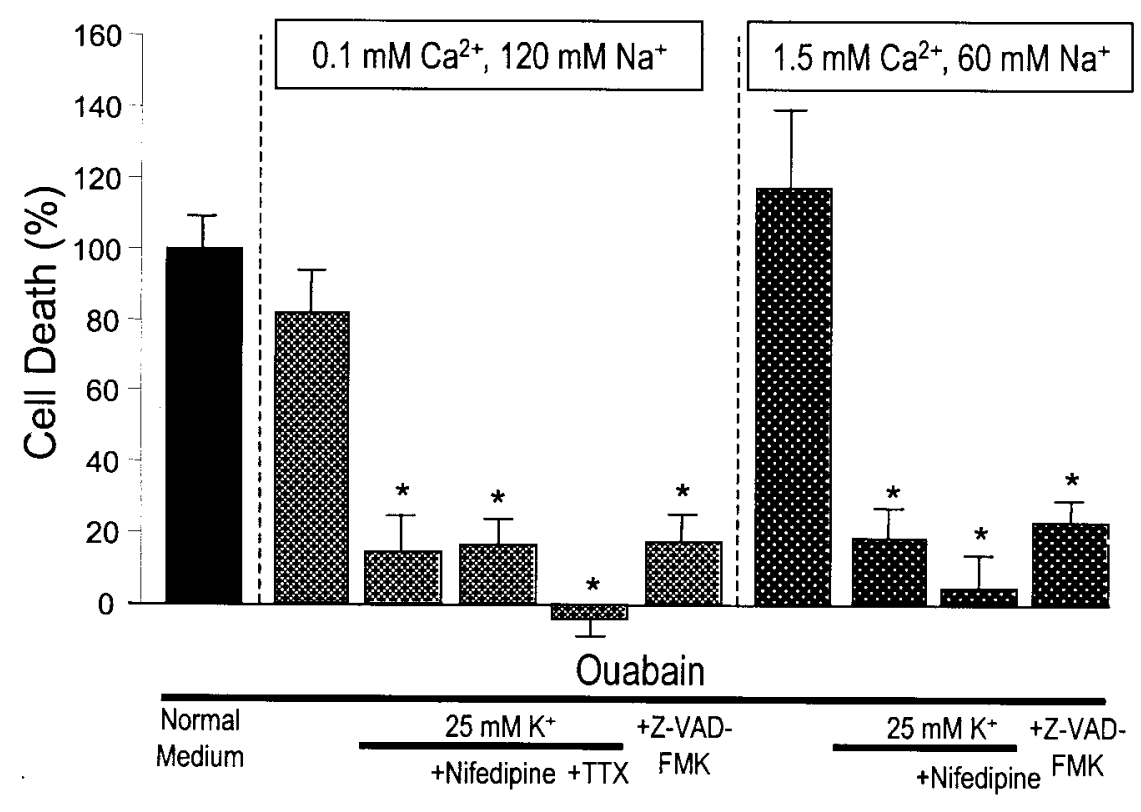
onset of exposure. Osmolarity was maintained by adding appropriate amounts of NMDG and HCl; $\mathrm{pH}$ was $7.4 . n=8-32 . * p<0.05$ compared with ouabain alone.

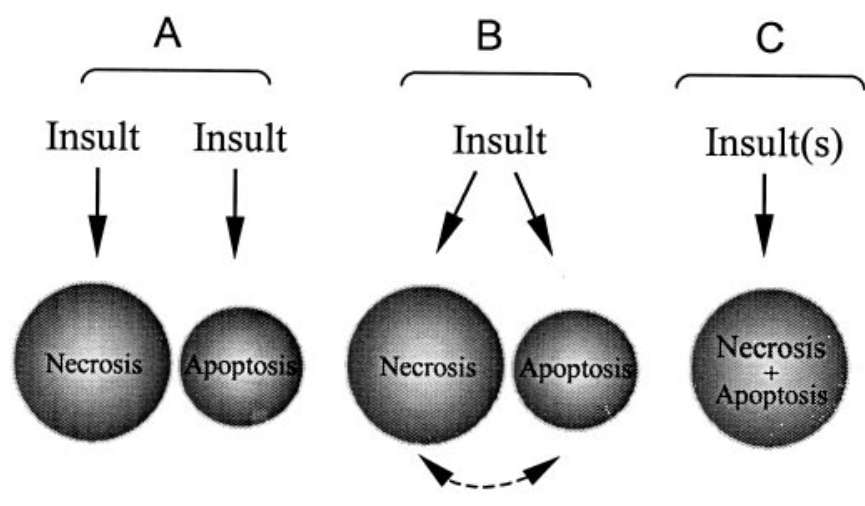

Figure 11. Cell death models for necrosis, apoptosis, and hybrid death. $A$, The conventional cell death model predicts that necrosis and apoptosis are triggered by separate insults and exhibit typical distinctive morphological changes in injured cells. $B$, Emerging opinion suggests that the same insult may induce either necrosis or apoptosis in different cells; alternatively, a necrotic injury may convert to apoptotic injury or vice versa. $C$, Recent observations and the present study support the third possibility that a single or multiple insult(s) may trigger parallel pathways leading to necrotic and apoptotic damages in the same cells, identified as hybrid cell death.

pathological features fulfills criteria for apoptosis or necrosis, we propose that this hybrid injury be recognized as a distinct form of cell death. We believe that this approach is necessary and of practical use for classifying widely observed but conceptually conf using lethal cellular events. The identification of hybrid death is particularly relevant to situations in which cells face multiple insults accompanied by impaired energy metabolism and elevated levels of endogenous ouabain. Study of the hybrid cell injury may facilitate the development of better therapies for this broad category of pathological conditions.

\section{REFERENCES}

Ahlemeyer B, Weintraut H, Schoner W (1992) Cultured chick-embryo heart cells respond differently to ouabain as measured by the increase in their intracellular $\mathrm{Na}^{+}$concentration. Biochem Biophys Acta 1137:135-142.
Ameisen JC (1994) Programmed cell death (apoptosis) and cell survival regulation: relevance to AIDS and cancer. AIDS 8:1197-1213.

Ankarcrona M, Dypbukt JM, Bonfoco E, Zhivotovsky B, Orrenius S, Lipton SA, Nicotera P (1995) Glutamate-induced neuronal death: a succession of necrosis or apoptosis depending on mitochondrial function. Neuron 15:961-973.

Archibald JT, White TD (1974) Rapid reversal of internal $\mathrm{Na}^{+}$and $\mathrm{K}^{+}$ contents of synaptosomes by ouabain. Nature 252:595-597.

Armstrong RC, Aja TJ, Hoang KD, Gaur S, Bai X, Alnemri ES, Litwack G, Karanewsky DS, Fritz LC, Tomaselli KJ (1997) Activation of the CED3/ICE-related protease CPP32 in cerebellar granule neurons undergoing apoptosis but not necrosis. J Neurosci 17:553-562.

Bagrov AY, Kuznetsova EA, Fedorova OV (1994) Endogenous digoxinlike factor in acute myocardial infarction. J Intern Med 235:63-67.

Balzan S, D'Urso G, Ghione S, Martinelli A, Montali U (2000) Selective inhibition of human erythrocyte $\mathrm{Na}^{+} / \mathrm{K}^{+}$ATPase by cardiac glycosides and by a mammalian digitalis like factor. Life Sci 67:1921-1928.

Barbiero G, Duranti F, Bonelli G, Amenta JS, Baccino FM (1995) Intracellular ionic variations in the apoptotic death of $\mathrm{L}$ cells by inhibitors of cell cycle progression. Exp Cell Res 217:410-418.

Beauvais F, Michel L, Dubertret L (1995) Human eosinophils in culture undergo a striking and rapid shrinkage during apoptosis. Role of $\mathrm{K}^{+}$ channels. J Leukoc Biol 57:851-855.

Bortner CD, Hughes Jr FM, Cidlowski JA (1997) A primary role for $\mathrm{K}^{+}$ and $\mathrm{Na}^{+}$efflux in the activation of apoptosis. J Biol Chem 272:32436-32442.

Bortner CD, Gomez-Angelats M, Cidlowski JA (2001) Plasma membrane depolarization without repolarization is an early molecular event in anti-Fas induced apoptosis. J Biol Chem 276:4304-4314.

Budzikowski AS, Huang BS, Leenen FH (1998) Brain "ouabain," a neurosteroid, mediates sympathetic hyperactivity in salt-sensitive hypertension. Clin Exp Hypertens 20:119-140.

Bundgaard H, Schmidt TA, Larsen JS, Kjeldsen K (1997) $\mathrm{K}^{+}$supplementation increases muscle. J Appl Physiol 82:1136-1144.

Cheung NS, Pascoe CJ, Giardina SF, John CA, Beart PM (1998) Micromolar L-glutamate induces extensive apoptosis in an apoptotic-necrotic continuum of insult-dependent, excitotoxic injury in cultured cortical neurones. Neuropharmacology 37:1419-1429.

Choi DW (1988) Calcium-mediated neurotoxicity: relationship to specific channel types and role in ischemic damage. Trends Neurosci 11:465-469.

Choi KH, Hama-Inaba H, Wang B, Haginoya K, Odaka T, Yamada T, Hayata I, Ohyama H (2000) UVC-induced apoptosis in human epithelial tumor A431 cells: sequence of apoptotic changes, involvement of caspase $(-8,-3)$ cascade. J Radiat Res (Tokyo) 41:243-258.

Chopp M, Li Y (1996) Apoptosis in focal cerebral ischemia. Acta Neurochir Suppl (Wien) 66:21-26.

Churchwell KB, Wright SH, Emma F, Rosenberg PA, Strange K (1996) NMDA receptor activation inhibits neuronal volume regulation after swelling induced by veratridine-stimulated $\mathrm{Na}^{+}$influx in rat cortical cultures. J Neurosci 16:7447-7457.

Colbourne F, Sutherland GR, Auer RN (1999) Electron microscopic 
evidence against apoptosis as the mechanism of neuronal death in global ischemia. J Neurosci 19:4200-4210.

Colom LV, Diaz ME, Beers DR, Neely A, Xie WJ, Appel SH (1998) Role of potassium channels in amyloid-induced cell death. J Neurochem 70:1925-1934.

Contreras RG, Shoshani L, Flores-Maldonado C, Lazaro A, Cereijido M (1999) Relationship between $\mathrm{Na}^{+}, \mathrm{K}^{+}$-ATPase and cell attachment. J Cell Sci 112:4223-4232.

Dallaporta B, Hirsch T, Susin SA, Zamzami N, Larochette N, Brenner C, Marzo I, Kroemer G (1998) Potassium leakage during the apoptotic degradation phase. J Immunol 160:5605-5615.

Dallaporta B, Marchetti P, de Pablo MA, Maisse C, Duc HT, Metivier D, Zamzami N, Geuskens M, Kroemer G (1999) Plasma membrane potential in thymocyte apoptosis. J Immunol 162:6534-6542.

De Angelis C, Haupert Jr GT (1998) Hypoxia triggers release of an endogenous inhibitor of $\mathrm{Na}^{+}, \mathrm{K}^{+}$-ATPase from midbrain and adrenal. Am J Physiol 274:F182-F188.

Deshpande J, Bergstedt K, Linden T, Kalimo H, Wieloch T (1992) Ultrastructural changes in the hippocampal CA1 region following transient cerebral ischemia: evidence against programmed cell death. Exp Brain Res 88:91-105.

Du C, Hu R, Csernansky CA, Hsu CY, Choi DW (1996) Very delayed infarction after mild focal cerebral ischemia: a role for apoptosis? J Cereb Blood Flow Metab 16:195-201.

Ejima A, Watanabe C, Koyama H, Satoh H (1999) Matrix interferences in the analysis of digested biological tissues with inductively coupled plasma-mass spectrometry. Biol Trace Elem Res 69:99-109.

Ferrandi M, Manunta P (2000) Ouabain-like factor: is this the natriuretic hormone? Curr Opin Nephrol Hypertens 9:165-171.

Gilbert M, Knox S (1997) Influence of Bcl-2 overexpression on $\mathrm{Na}^{+} /$ $\mathrm{K}^{+}$-ATPase pump activity: correlation with radiation-induced programmed cell death. J Cell Physiol 171:299-304.

Gottron FJ, Ying HS, Choi DW (1997) Caspase inhibition selectively reduces the apoptotic component of oxygen-glucose deprivationinduced cortical neuronal cell death. Mol Cell Neurosci 9:159-169.

Grynkiewicz G, Poenie M, Tsien RJ (1985) A new generation of $\mathrm{Ca}^{2+}$ indicators with greatly improved fluorescence properties. J Biol Chem 260:3440-3450.

Gwag BJ, Lobner D, Koh JY, Wie MB, Choi DW (1995) Blockade of glutamate receptors unmasks neuronal apoptosis after oxygen-glucose deprivation in vitro. Neuroscience 68:615-619.

Hamlyn JM, Hamilton BP, Manunta P (1996) Endogenous ouabain, sodium balance and blood pressure: a review and a hypothesis. J Hypertens 14:151-167.

Hirsch T, Marchetti P, Susin SA, Dallaporta B, Zamzami N, Marzo I, Geuskens M, Kroemer G (1997) The apoptosis-necrosis paradox. Apoptogenic proteases activated after mitochondrial permeability transition determine the mode of cell death. Oncogene 15:1573-1581.

Hughes Jr FM, Cidlowski JA (1999) Potassium is a critical regulator of apoptotic enzymes in vitro and in vivo. Adv Enzyme Regul 39:157-171.

Hughes Jr FM, Bortner CD, Purdy GD, Cidlowski JA (1997) Intracellular $\mathrm{K}^{+}$suppresses the activation of apoptosis in lymphocytes. J Biol Chem 272:30567-30576.

Isaev NK, Stelmashook EV, Halle A, Harms C, Lautenschlager M, Weih M, Dirnagl U, Victorov IV, Zorov DB (2000) Inhibition of $\mathrm{Na}^{+}, \mathrm{K}^{+}$ATPase activity in cultured rat cerebellar granule cells prevents the onset of apoptosis induced by low potassium. Neurosci Lett 283:41-44.

Johnson Jr EM, Koike T, Franklin J (1992) A "calcium set-point hypothesis" of neuronal dependence on neurotrophic factor. Exp Neurol 115:163-166.

Joza N, Susin SA, Daugas E, Stanford WL, Cho SK, Li CY, Sasaki T, Elia AJ, Cheng HY, Ravagnan L, Ferri KF, Zamzami N, Wakeham A, Hakem R, Yoshida H, Kong YY, Mak TW, Zuniga-Pflucker JC, Kroemer G, Penninger JM (2001) Essential role of the mitochondrial apoptosis-inducing factor in programmed cell death. Nature 410:549-554.

Kawazoe N, Aiuchi T, Masuda Y, Nakajo S, Nakaya K (1999) Induction of apoptosis by bufalin in human tumor cells is associated with a change of intracellular concentration of $\mathrm{Na}+$ ions. $\mathrm{J}$ Biochem (Tokyo) 126:278-286

Kerr JF, Wyllie AH, Currie AR (1972) Apoptosis: a basic biological phenomenon with wide-ranging implications in tissue kinetics. Br J Cancer 26:239-257.

Kim YH, Kim EY, Gwag BJ, Sohn S, Koh JY (1999) Zinc-induced cortical neuronal death with features of apoptosis and necrosis: mediation by free radicals. Neuroscience 89:175-182.

Kim-Han JS, Lovett E, Rothman SM, Dugan LL (1999) NMDA receptor inhibition induces free radical generation and cell death of cortical neurons. Soc Neurosci Abstr 25:1777.

Koh JY, Wie MB, Gwag BJ, Sensi SL, Canzoniero LM, Demaro J, Csernansky C, Choi DW (1995) Staurosporine-induced neuronal apoptosis. Exp Neurol 135:153-159.

Krick S, Platoshyn O, Sweeney M, Kim H, Yuan JX (2001) Activation of $\mathrm{K}^{+}$channels induces apoptosis in vascular smooth muscle cells. Am J Physiol Cell Physiol 280:C970-C979.
Kristian T, Siesjo BK (1996) Calcium-related damage in ischemia. Life Sci 59:357-367.

Kroemer G, Petit P, Zamzami N, Vayssiere JL, Mignotte B (1995) The biochemistry of programmed cell death. FASEB J 9:1277-1287.

Lang F, Madlung J, Siemen D, Ellory C, Lepple-Wienhues A, Gulbins E (2000) The involvement of caspases in the CD95(Fas/Apo-1) but not swelling-induced cellular taurine release from Jurkat T-lymphocytes. Pflügers Arch 440:93-99.

Lees GJ (1991) Inhibition of sodium-potassium-ATPase: a potentially ubiquitous mechanism contributing to central nervous system neuropathology. Brain Res Brain Res Rev 16:283-300.

Leist M, Gantner F, Kunstle G, Bohlinger I, Tiegs G, Bluethmann H, Wendel A (1996) The 55-kD tumor necrosis factor receptor and CD95 independently signal murine hepatocyte apoptosis and subsequent liver failure. Mol Med 2:109-124.

Lijnen P, Hespel P, Lommelen G, Laermans M, M'Buyamba-Kabangu JR, Amery A (1986) Intracellular sodium, potassium and magnesium concentration, ouabain-sensitive ${ }^{86}$ rubidium-uptake and sodium-efflux and $\mathrm{Na}^{+}, \mathrm{K}^{+}$-cotransport activity in erythrocytes of normal male subjects studied on two occasions. Methods Find Exp Clin Pharmacol 8:525-533.

Lipton SA, Nicotera P (1998) Calcium, free radicals and excitotoxins in neuronal apoptosis. Cell Calcium 23:165-171.

Liu XZ, Xu XM, Hu R, Du C, Zhang SX, McDonald JW, Dong HX, Wu YJ, Fan GS, Jacquin MF, Hsu CY, Choi DW (1997) Neuronal and glial apoptosis after traumatic spinal cord injury. $J$ Neurosci 17:5395-5406.

Lotem J, Kama R, Sachs L (1999) Suppression or induction of apoptosis by opposing pathways downstream from calcium-activated calcineurin Proc Natl Acad Sci USA 96:12016-12020.

Maeno E, Ishizaki Y, Kanaseki T, Hazama A, Okada Y (2000) Normotonic cell shrinkage because of disordered volume regulation is an early prerequisite to apoptosis. Proc Natl Acad Sci USA 97:9487-9492.

Majno G, Joris I (1995) Apoptosis, oncosis, and necrosis. An overview of cell death. Am J Pathol 146:3-15.

McGrail KM, Phillips JM, Sweadner KJ (1991) Immunofluorescent localization of three $\mathrm{Na}, \mathrm{K}-\mathrm{ATPase}$ isozymes in the rat central nervous system: both neurons and glia can express more than one $\mathrm{Na}, \mathrm{K}$ ATPase. J Neurosci 11:381-391.

Miller C, Kennington L, Cooney R, Kohjimoto Y, Cao LC, Honeyman T, Pullman J, Jonassen J, Scheid C (2000) Oxalate toxicity in renal epithelial cells: characteristics of apoptosis and necrosis. Toxicol Appl Pharmacol 162:132-141.

Mills JC, Stone NL, Pittman RN (1999) Extranuclear apoptosis. The role of the cytoplasm in the execution phase. J Cell Biol 146:703-708.

Miura M, Yuan J (1996) Regulation of programmed cell death by interleukin-1 beta-converting enzyme family of proteases. Adv Exp Med Biol 389:165-172.

Molthagen M, Schachner M, Bartsch U (1996) Apoptotic cell death of photoreceptor cells in mice deficient for the adhesion molecule on glia (AMOG, the beta 2- subunit of the Na, K-ATPase). J Neurocytol 25:243-255

Nakajima W, Ishida A, Lange MS, Gabrielson KL, Wilson MA, Martin LJ, Blue ME, Johnston MV (2000) Apoptosis has a prolonged role in the neurodegeneration after hypoxic ischemia in the newborn rat. J Neurosci 20:7994-8004.

Nicotera P, Lipton SA (1999) Excitotoxins in neuronal apoptosis and necrosis. J Cereb Blood Flow Metab 19:583-591.

Nobel CS, Aronson JK, van den Dobbelsteen DJ, Slater AF (2000) Inhibition of $\mathrm{Na}^{+} / \mathrm{K}^{+}$-ATPase may be one mechanism contributing to potassium efflux and cell shrinkage in CD95-induced apoptosis. Apoptosis 5:153-163.

Okuno S, Shimizu S, Ito T, Nomura M, Hamada E, Tsujimoto Y, Matsuda H (1998) Bcl-2 prevents caspase-independent cell death. J Biol Chem 273:34272-34277.

Olej B, dos Santos NF, Leal L, Rumjanek VM (1998) Ouabain induces apoptosis on PHA-activated lymphocytes. Biosci Rep 18:1-7.

Orlov SN, Taurin S, Thorin-Trescases N, Dulin NO, Tremblay J, Hamet $\mathrm{P}$ (2000) Inversion of the intracellular $\mathrm{Na}^{+} / \mathrm{K}^{+}$ratio blocks apoptosis in vascular smooth muscle cells by induction of RNA synthesis. Hypertension 35:1062-1068.

Papadimitriou JC, Drachenberg CB, Shin ML, Trump BF (1994) Ultrastructural studies of complement mediated cell death: a biological reaction model to plasma membrane injury. Virchows Arch 424:677-685.

Park IC, Park MJ, Choe TB, Jang JJ, Hong SI, Lee SH (2000) TNF- $\alpha$ induces apoptosis mediated by AEBSF-sensitive serine protease(s) that may involve upstream caspase-3/CPP32 protease activation in a human gastric cancer cell line. Int J Oncol 16:1243-1248.

Penning LC, Denecker G, Vercammen D, Declercq W, Schipper RG, Vandenabeele P (2000) A role for potassium in TNF-induced apoptosis and gene-induction in human and rodent tumour cell lines. Cytokine 12:747-750.

Polverino AJ, Patterson SD (1997) Selective activation of caspases dur- 
ing apoptotic induction in HL-60 cells. Effects of a tetrapeptide inhibitor. J Biol Chem 272:7013-7021.

Portera-Cailliau C, Price DL, Martin LJ (1997) Excitotoxic neuronal death in the immature brain is an apoptosis-necrosis morphological continuum. J Comp Neurol 378:70-87.

Raff MC, Barres BA, Burne JF, Coles HS, Ishizaki Y, Jacobson MD (1993) Programmed cell death and the control of cell survival: lessons from the nervous system. Science 262:695-700.

Reed JC (1999) Dysregulation of apoptosis in cancer. J Clin Oncol 17:2941-2953.

Rose K, Goldberg MP, Choi DW (1993) Cytotoxicity in murine cortical cell culture. In: Methods in toxicology, Vol 1, Part A, In vitro biological methods (Tyson CA, Frazier JM, eds), pp 46-60. San Diego: Academic.

Sanguinetti MC, Kass RS (1984) Voltage-dependent block of calcium channel current in the calf cardiac Purkinje fiber by dihydropyridine calcium channel antagonists. Circ Res 55:336-348.

Schumer M, Colombel MC, Sawczuk IS, Gobe G, Connor J, O’Toole KM, Olsson CA, Wise GJ, Buttyan R (1992) Morphologic, biochemical, and molecular evidence of apoptosis during the reperfusion phase after brief periods of renal ischemia. Am J Pathol 140:831-838.

Shimizu S, Eguchi Y, Kamiike W, Itoh Y, Hasegawa J, Yamabe K, Otsuki Y, Matsuda H, Tsujimoto Y (1996) Induction of apoptosis as well as necrosis by hypoxia and predominant prevention of apoptosis by $\mathrm{Bcl}-2$ and Bcl- $X_{\mathrm{I}}$. Cancer Res 56:2161-2166.

Siesjo BK (1992) Pathophysiology and treatment of focal cerebral ischemia. Part I: Pathophysiology. J Neurosurg 77:169-184.

Sohn S, Kim EY, Gwag BJ (1998) Glutamate neurotoxicity in mouse cortical neurons: atypical necrosis with DNA ladders and chromatin condensation. Neurosci Lett 240:147-150.

Sperandio S, de Belle I, Bredesen DE (2000) An alternative, nonapoptotic form of programmed cell death. Proc Natl Acad Sci USA 97:14376-14381.

Takadera T, Matsuda I, Ohyashiki T (1999) Apoptotic cell death and caspase-3 activation induced by $N$-methyl-D-aspartate receptor antagonists and their prevention by insulin-like growth factor I. J Neurochem 73:548-556.

Takashi E, Ashraf M (2000) Pathologic assessment of myocardial cell necrosis and apoptosis after ischemia and reperfusion with molecular and morphological markers. J Mol Cell Cardiol 32:209-224.

Thompson CB (1995) Apoptosis in the pathogenesis and treatment of disease. Science 267:1456-1462.

Thornberry NA, Rano TA, Peterson EP, Rasper DM, Timkey T, GarciaCalvo M, Houtzager VM, Nordstrom PA, Roy S, Vaillancourt JP, Chapman KT, Nicholson DW (1997) A combinatorial approach defines specificities of members of the caspase family and granzyme B. Functional relationships established for key mediators of apoptosis. J Biol Chem 272:17907-17911.

Toescu EC (1998) Apoptosis and cell death in neuronal cells: where does $\mathrm{Ca}^{2+}$ fit in? Cell Calcium 24:387-403.

Tsujimoto Y, Shimizu S, Eguchi Y, Kamiike W, Matsuda H (1997) Bcl-2 and Bcl-xL block apoptosis as well as necrosis: possible involvement of common mediators in apoptotic and necrotic signal transduction pathways. Leukemia 11[Suppl 3]:380-382.

van Lookeren Campagne M, Gill R (1996) Ultrastructural morphologi- cal changes are not characteristic of apoptotic cell death following focal cerebral ischaemia in the rat. Neurosci Lett 213:111-114.

Vander Heiden MG, Chandel NS, Schumacker PT, Thompson CB (1999) Bcl-xL prevents cell death following growth factor withdrawal by facilitating mitochondrial ATP/ADP exchange. Mol Cell 3:159-167.

Vaux DL, Haecker G, Strasser A (1994) An evolutionary perspective on apoptosis. Cell 76:777-779.

Verheye-Dua FA, Bohm L (2000) Influence of apoptosis on the enhancement of radiotoxicity by ouabain. Strahlenther Onkol 176:186-191.

Villalba M, Bockaert J, Journot L (1997) Concomitant induction of apoptosis and necrosis in cerebellar granule cells following serum and potassium withdrawal. NeuroReport 8:981-985.

Wang L, Xu D, Dai W, Lu L (1999) An ultraviolet-activated $\mathrm{K}^{+}$channel mediates apoptosis of myeloblastic leukemia cells. J Biol Chem $274: 3678-3685$

Wang X, Xiao AY, Ichinose T, Yu SP (2000) Effects of tetraethylammonium analogues on apoptosis and membrane currents in cultured cortical neurons. J Pharmacol Exp Ther 295:524-530.

Warny M, Kelly CP (1999) Monocytic cell necrosis is mediated by potassium depletion and caspase- like proteases. Am J Physiol 276:C717-C724.

Watts AG, Sanchez-Watts G, Emanuel JR, Levenson R (1991) Cellspecific expression of mRNAs encoding $\mathrm{Na}^{+}, \mathrm{K}^{+}$-ATPase alpha- and beta-subunit isoforms within the rat central nervous system. Proc Natl Acad Sci USA 88:7425-7429.

Wyllie AH, Kerr JF, Currie AR (1980) Cell death: the significance of apoptosis. Int Rev Cytol 68:251-306.

Xiao AY, Yu SP (2000) Ionic mechanism of ouabain-induced concurrent apoptosis and necrosis in cultured cortical neurons. Soc Neurosci Abstr 26:606.

Xie Y, Dengler K, Zacharias E, Wilffert B, Tegtmeier F (1994) Effects of the sodium channel blocker tetrodotoxin (TTX) on cellular ion homeostasis in rat brain subjected to complete ischemia. Brain Res 652:216-224

Yu SP, Choi DW (2000) Ions, cell volume, apoptosis. Proc Natl Acad Sci USA 97:9360-9362.

Yu SP, Yeh CH, Sensi SL, Gwag BJ, Canzoniero LM, Farhangrazi ZS, Ying HS, Tian M, Dugan LL, Choi DW (1997) Mediation of neuronal apoptosis by enhancement of outward potassium current. Science 278:114-117.

Yu SP, Farhangrazi ZS, Ying HS, Yeh CH, Choi DW (1998) Enhancement of outward potassium current may participate in beta-amyloid peptide-induced cortical neuronal death. Neurobiol Dis 5:81-88.

Yu SP, Yeh C, Strasser U, Tian M, Choi DW (1999a) NMDA receptormediated $\mathrm{K}^{+}$efflux and neuronal apoptosis. Science 284:336-339.

Yu SP, Yeh CH, Gottron F, Wang X, Grabb MC, Choi DW (1999b) Role of the outward delayed rectifier $\mathrm{K}^{+}$current in ceramide-induced caspase activation and apoptosis in cultured cortical neurons. J Neurochem 73:933-941.

Yu SP, Canzoniero LMT, Choi DW (2001) Ion homeostasis and apoptosis. Curr Opin Cell Biol 13:405-411.

Zhivotovsky B, Gahm A, Ankarcrona M, Nicotera P, Orrenius S (1995) Multiple proteases are involved in thymocyte apoptosis. Exp Cell Res 221:404-412. 